\title{
Estimating Capital Investment and Facility Footprint in Cell Therapy Facilities
}

Tania D Pereira Chilima ${ }^{\mathrm{a}}$, Fabien Moncaubeig ${ }^{\mathrm{b} 1}$, Suzanne S. Farid ${ }^{\mathrm{a}}$

${ }^{a}$ The Advanced Centre for Biochemical Engineering, Dept. of Biochemical Engineering, University College London, Gordon Street, London WC1H OAH, UK

${ }^{b}$ Pall Life Sciences, 5 Harbourgate Business Park, Southampton Road, Portsmouth, Hampshire PO6 4BQ, UK

\section{*Corresponding author:}

Prof Suzanne Farid - s.farid@ucl.ac.uk

Tel +44 (0) 2076794415

Fax +44 (0) 2079163943

Running title: Cell Therapy Facility Investment and Footprint

${ }^{1}$ Currently at Biotech Innovation Program Partners, Cugnaux, France 


\section{Abstract}

Estimations of the facility footprint and fixed capital investment (FCI) of cell therapy (CT) facilities need to consider the unique features of the single-use technologies (SUTs) selected for CT manufacture (e.g. cleanroom containment requirement, capacity, automation) and the product nature that impacts scale-out versus scale-up approaches. A novel detailed factorial methodology is proposed for estimating FCI and footprint for bespoke stick-built cell therapy facilities that accounts for technology-specific factors for key cell culture technologies as well as the implications of SUTs, open versus closed operations and the commercialisation scenario selected. This was used to derive benchmark values for short-cut cost and area factors for typical cell therapy facilities according to the technologies selected. The results provide project-specific ratios for equipment purchase costs to facility footprint (area factor) and for FCI to total equipment purchase costs (cost factor or "Lang” factor). Area factors $\left(\$ / \mathrm{m}^{2}\right)$ were 675-6,815 and the cost factors were 2.3-8.5 for a greenfield project in a medium-developed country. The case study shows that for the same output facility footprints and FCI values are on average 6 times higher for autologous processes than allogeneic processes. This is attributed to economies of scale achieved with scale-up for allogeneic cell therapy manufacture. This study can be used to predict the commercial FCI and facility footprint during early stages of process development.

Key words: Fixed capital investment, facility footprint, cleanrooms, cell therapy, mesenchymal stem cells, CAR T-cells 


\section{Abbreviations}

$\begin{array}{cl}\text { AMLFM } & \text { Automated multilayer flask manipulator } \\ \text { BSC } & \text { Biosafety cabinet } \\ \text { CAR T-cell } & \text { Chimeric antigen receptor T-cell } \\ \text { CIP } & \text { Cleaning-in-place } \\ \text { CT } & \text { Cell therapy } \\ F_{a} & \text { Area factor } \\ \text { FACS } & \text { Fluorescence-activated cell sorting } \\ \text { FBC } & \text { Fluidised bed centrifuge } \\ F_{C} & \text { Cost factor } \\ \text { FCI } & \text { Fixed capital investment } \\ \text { HFB } & \text { Hollow fibre bioreactor } \\ \text { HVAC } & \text { Heating, ventilation and air conditioning systems } \\ \text { INC40 } & \text { 40-layer flask incubator } \\ \text { INT } & \text { Integrated USP/DSP platform } \\ \text { ISO } & \text { International organisation for standardization } \\ \text { MSC } & \text { Mesenchymal stem cell } \\ \text { MLF } & \text { Multilayer flask } \\ \text { MLINC } & \text { Multilayer flasks incubator } \\ \text { MPB } & \text { Multi-plate bioreactor } \\ \text { QC } & \text { Quality control } \\ \text { PCR } & \text { Polymerase chain reaction } \\ \text { RMB } & \text { Rocking motion bioreactor } \\ \text { SIP } & \text { Steaming-in-place } \\ \text { SS } & \text { Stainless steel } \\ \text { SSB } & \text { Static suspension bag } \\ \text { STR } & \text { Stirred tank bioreactor } \\ \text { SU } & \text { Single-use } \\ \text { SUT } & \text { Single-use technology } \\ \text { TCEPC } & \text { Total core equipment purchase costs } \\ \text { WFI } & \text { Water for injection } \\ & \end{array}$




\section{Introduction}

Cell therapy products can treat and possibly cure a number of unmet indications [1]-[21]. As these products cannot be sterilized, CT manufacture often employs single-use technologies (SUTs) to reduce the risks of cross-contamination [22]. Given that manufacturing processes tend to differ significantly across different classes of cell therapy products (e.g. chimeric antigen receptor T-cell therapy $\mathrm{v}$ mesenchymal stem cell therapy), a variety of SUTs have become available in order to meet product-specific needs in cell therapy bioprocessing. The distinctive features of these SUTs result in technology-specific facility layouts and fixed capital investment (FCI) requirements, which diverge from traditional stainless steel (SS) biotechnology facilities [23]-[36]. Therefore, it is crucial to derive novel methods for facility footprint and FCI evaluation that take into account the unique attributes of cell therapy facilities so as to increase the accuracy of estimates and help cell therapy companies make better informed decisions during process development. Table 1 summarises reported values for the footprint and FCI of current cell therapy facilities.

Previous studies on FCI and footprint evaluation for bioprocess applications, have not covered the subject of cell therapy facilities as these were focused primarily on SS and SU facilities for protein manufacture [37]-[43]. This article will highlight the effect of technology selection on facility footprint and FCI estimates, and provide short-cut methods for footprint and FCI evaluation for cell therapy facilities that not only take into account technology-specific features, but also consider project-dependant factors such as manufacturing scale and geographic location.

SUTs were first introduced in 1970's in the form of filters and capsules [44], [45]. Since then, the use of these technologies has been extended to a number of applications including storage and mixing bags, bioreactors, and downstream processing solutions [44]-[53]. The adoption of SUTs carries a number of benefits such as lower water usage, faster changeover times and 
reduced risk of cross-contamination [45]-[47], [53]-[58]. Challenges to the implementation of these technologies include scale and configuration restrictions, source availability and the creation of leachables and extractables [47], [59], [60].

The SUTs for cell therapy bioprocessing currently available differ significantly in a number of aspects including price, footprint, degree of automation and control over process parameters (e.g. $\mathrm{pH}$ and temperature). In upstream processing, for applications that require very low manufacturing scales, manual cell culture vessels are often employed. These include T-flasks, multilayer flasks, gas permeable vessels and static suspension bags [23], [24], [28], [30], [32], [36], [61], [62]. Key benefits of using manual SUTs include the fact that operators are familiar with these cell culture vessels as these are routinely used in laboratories. Moreover, manual cell culture vessels offer relative low equipment and consumables costs [62]-[64]. The implementation of these cell culture vessels in commercial scale manufacture of cell therapy products poses significant challenges due to the difficulty in achieving functionally closed processes, which increases facility-related costs. Moreover, the high number of manual interventions required in processes using manual technologies affects the robustness of the process and increases labour costs [62]-[64]. When using multilayer flasks for cell culture, these challenges can be addressed through the integration of robotics to aid manipulation [30], [32], [63], [65].

An additional approach to promote process robustness and decrease labour and facility-related costs include the implementation of SU bioreactors, which can process cell culture volumes of up to 2,000L[62], [63]. These cell culture vessels combine automation with process control and are available in a number of different configurations such as multi-plate reactors, packed-bed reactors, hollow-fibre reactors, rocking motion bioreactors and stirred tank reactors with microcarriers [25], [30], [32]-[34], [61]-[63]. 
SUTs for downstream processing of cell therapy products range from filtration techniques such as tangential flow filtration and spinning membrane filtration [66]-[70] to batch and continuous centrifugation [22], [63], [64], [66], [68], [71]-[76]. Moreover, fully integrated and automated systems for cell therapy manufacture that incorporate both upstream and downstream unit operations are also available [64], [77], [78]. These however have very limited capacity and are therefore appropriate for patinet-specifc applications [64], [77].

FCI for pharma/biotech facilities is computed typically using the "Lang factor method" [79]. In this method, a ratio between the total equipment purchase costs (including utilities) and FCI is derived from historical projects [79]. These costs included: equipment, piping, instrumentation, electrical work, building, utilities, site development and auxiliary buildings [37]. Additional factors are also applied in order to account for design and engineering, contractor fees as well as contingency [79]. The "Lang factor" ratio has been estimated to be between 3.10-4.74 for pharma facilities and 4-8 for biotech facilities [40], [79].

Given the unique product, process and technology features of cell therapy facilities, it is important to investigate the suitability of a universal "Lang factor" for facilities using different manufacturing platforms. For example, in cell therapy bioprocessing there are no protein purification unit operations, which shortens the DSP. Moreover, given that the cells are the product, in addition to the use of SUTs, methods to achieve adequate purity levels include the implementation of strigent cleanroom enviromental control systems. The use of SUTs reduces the requirement of steam and WFI which will reduce the facility and equipment costs associated with utilities. Environmental control is achieved by monitoring parameters such as pressure, temperature and humidity through the use of air filters and regular maintenance using heating, ventilation and air conditioning systems (HVAC), as failure to do so may influence contamination by microorganisms and jeopardise the maintenance of low particle counts in the 
air [80], [81]. Different degrees of environmental control strategies are applied to different area classifications depending on the type of process used (e.g. closed v open processing). For example, a Grade B (ISO 7) cleanroom are suited for open processing and may require 50 air changes per hour. A grade D clean room (ISO 9) can be used for closed processing and only requires 12 [46]. Table 2 shows how the reported values for costs $/ \mathrm{m}^{2}$ vary with area classification. As the cleanroom classification affects the cleanroom building fit-out and running costs [46], [82] and is highly dependent on the type of technology used, when estimating FCI and facility footprint, it is crucial to consider the features of the technologies used for cell therapy manufacture.

This article provides a detailed factorial methodology for FCI and facility footprint estimation for cell therapy applications, which is highly tailored to key project-specific features such as technology selected, open versus closed operations and manufacturing scale. This method was used to derive benchmark project-specific ratios for short-cut FCI and facility footprint evaluation for stick-built facility designs. 


\section{Materials and methods}

\subsection{Methodology description}

A detailed framework for FCI and facility footprint evaluation was built and used to calculate facility footprint as the sum of the footprint of the different sections within the facility. Six main sections where identified, as these are likely to have different cleanroom classifications. These sections were: product manufacture, clean circulation space, product testing area, waste circulation space, general space and plant space. The footprint of each of these sections was computed using the equations detailed in the Supplementary section of this article and the assumptions listed in Table 3 and Table 4.

The product manufacture area corresponds to the main processing area where all product manufacture activities occur including inoculation, cell culture, downstream process and formulation and fill. These operations are carried out in cleanrooms that have the highest ISO qualification within the facility. The clean circulation space corresponds to the airlocks and corridors that separate the product manufacture area and the general area within the facility. The product testing area encompasses the space required for QC labs, microbiology labs, PCR rooms as well as the corridors and personnel and material airlocks. The waste circulation area comprises waste disposal rooms, corridors and personnel changing rooms, and the general space within the facility includes logistics rooms, meeting rooms, offices, cold rooms, general corridors, loading docks, WC, staircases and facility reception areas.

The plant area is where the utilities reside (including the HVAC systems). This area is smaller in SU facilities than in SS facilities as CIP and SIP activities are reduced[40], [45], [46], [51], [53], [54], [56], [58], [59], [83]-[85]. Moreover, this case study assumes that no media and buffer preparation is carried out within the facility as these materials are pre-made before arriving to the manufacturing site. Therefore, additional space for cold storage rooms is necessary to store these materials. 
FCI was divided into direct FCI and non-direct FCI. In this case study, the cost categories included in the direct FCI costs were: the core process equipment costs, process support equipment costs, QC equipment costs, logistics equipment costs, environment monitoring systems (EMS), main process equipment installation costs, building shell costs, building fitout costs, contractor fees, land costs and yard improvement costs.

The core process equipment includes the key equipment required for product manufacture such as bioreactor skids, biosafety cabinets, incubators and downstream process units. The process support equipment costs correspond to the costs of all support equipment including benchtop centrifuges, pumps, trolleys and racks etc. The QC equipment correspond to the costs associated to all equipment required for QC testing such as filter integrity testers, incubators and fluorescence-activated cell sorting (FACS) systems etc. The EMS costs are the costs associated with the equipment required for environment monitoring (e.g. probes). The process equipment installation costs are the costs for installing the core process equipment into the facility. Logistics equipment include fridges, freezers and roller racking. The building shell costs are the costs of the base building while the fit-out costs include the majority of the costs related to building works such as partitions, floors, ceilings, air conditioning, duck work, electrical distribution, lighting, controls and monitoring, pipework and insulation etc. The contractor fees is the payment made to the contractor. The land and yard improvement costs are the costs associated with purchasing the initial construction site and the costs of any additional work required prior to construction. The non-direct cost categories included in the FCI calculation were project design, engineering management and consultant fees and contingency costs, which account for unforeseen events which may increase the FCI and/or delay the process (e.g. strikes and natural disasters). The costs of each of these categories was computed using the equations in the Supplementary section of this article and the assumptions in Table 4, Table 5 and Supplementary Table 1. 


\subsection{Case study setup}

The aim of this case study was to first validate the detailed methodology for FCI and facility footprint evaluation described in the previous session. This methodology was used to help understand the trends in FCI and facility footprint for cell therapy manufacturing processes using different combinations of technologies referred to as manufacturing platforms with the aim of deriving benchmark correlations for project-specific short-cut FCI and facility footprint estimation.

\subsubsection{Validation of the detailed factorial methodology for estimating FCI and footprint for bespoke cell therapy facilities}

The detailed framework for computing FCI and facility footprint was validated in order to increase the confidence in the results attained using the short-cut method for FCI and facility footprint evaluation. This was done by comparing the FCI and facility footprint results attained with the novel factorial method previously described against the values provided by eXmoor Pharma Concepts Ltd (Bristol, UK) for the same scenario. The scenario selected for this comparison was of an allogeneic MSC-based cell therapy process using automated cell factories for cell expansion and a fluidised bed centrifuge (FBC) for wash and recovery. The equipment list established for this scenario included biosafety cabinets (BSCs), multilayer flask incubators (MLINC), 40-layer flask incubators (INC40), automated multilayer manipulators (AMLFM) and FBCs. The number of BSCs, MLINCs, INC40s, AMLFMs and FBCs modelled in this scenario were 4, 2, 5, 2 and 1 respectively.

\subsubsection{FCI and facility footprint for cell therapy facilities}

The detailed framework for computing FCI and facility footprint was used to evaluate values for hypothetical cell therapy facilities using different technologies across annual demands ranging from 500 patients per year to 10,000 patients per year. The study was then extended to 
help understand the relationships between technology selection, annual demand, FCI and facility footprint. The understanding of these relationships was strengthened by the identification of key parameters contributing towards facility footprint and FCI.

\subsubsection{Estimating project-specific cost factors for FCI evaluation}

FCI estimates may vary with geographic location. Therefore, the benchmark values for ratios of FCI to core process equipment (cost factors or “Lang” factors) were adjusted by multiplying these by geographic location factors. The geographic location factors were estimated according to the degree of economic development of the geographic regions being considered. For example for regions with relatively low economic development (e.g. Mexico and India), this factor was assumed to be 0.85 . For regions with medium economic development such as the Gulf Coast of the US, this value was assumed to be 1, and for sites with high economic development such as Western Europe and the West Coast of the US this value was assumed to be 1.25 [37]. Moreover, project requirements may also vary according to the condition of the construction site. Facilities may be built on a greenfield site, brownfield site or an existing facility maybe refurbished to allow for cell therapy manufacture. In scenarios where facilities are to be built on a brownfield site, it was assumed that no yard improvements were required, hence these costs were removed. In scenarios where a facility was to be refurbished (i.e. an existing shell is available), it was assumed that the land costs, yard improvements and shell costs were null, so that the facility shell was rented and refurbished.

\subsubsection{Process overview}

In order to evaluate the trends in FCI and facility footprint for cell therapy facilities with the aim of deriving project-specific cost and area factors, multiple hypothetical facilities for autologous and allogeneic cell therapy manufacture were modelled. The unit operations carried out within these hypothetical facilities were pre-cell culture steps (e.g. cell activation,), cell culture, downstream process and formulation and fill. 
The allogeneic process modelled in this case study was based on a 21 day process for the manufacture of mesenchymal stem cells (MSCs). This process is described in detail in Pereira Chilima et al [63] and the autologous process modelled was based on the manufacturing process of a lentivirus-based chimeric antigen receptor T-cell (CAR T-cell) process lasting 13 days (described in detail in Pereira Chilima et al [64]).

For facilities manufacturing autologous CAR T-cells, it was assumed that the number of product manufacture rooms was dependent on the manufacturing platform being used and proportional to the number of processes carried out in parallel. For facilities producing allogeneic MSC-based products on the other hand, it was assumed that the starting material was retrieved from a frozen cell bank and therefore an inoculation stage using T-flasks in biosafety cabinets surrounded by a Grade B cleanroom was required. Moreover, in these facilities it was also assumed that the product manufacture area was divided into four main suites: inoculation room, cell culture room, DSP room and formulation and fill room.

\subsubsection{Key assumptions}

The dose size of both autologous and allogeneic cell therapy products modelled in this case study was assumed to be $100 \mathrm{M}$ cells. It was assumed also that the hypothetical facilities considered in this article were built on a greenfield site in a medium economically developed area and that they were active for 335 days per year.

The majority of the manufacturing platforms considered in this article allow for functionally closed processes, which can be carried out in a Grade C cleanroom. This trend excludes multilayer flasks for autologous CAR T-cell therapy manufacture, as these require multiple open steps throughout the manufacturing process, and hence must be operated in biosafety cabinets surrounded by Grade B processing cleanrooms. The characteristics of the technologies 
combined together to form the different manufacturing platforms are summarized in Table 5. All other cost and footprint assumptions used in this case study are summarised in Table 4.

\section{Results and discussion}

\subsection{Validating the novel detailed factorial methodology for estimating FCI and facility footprint}

In order to validate the FCI and facility footprint predictions generated using the detailed framework for by the FCI and facility footprint estimation, these were compared with values kindly provided by a design consultancy, eXmoor Pharma Concepts, for the same scenario. This comparison is shown in Figure 2. Figure 2 illustrates a good agreement in the estimates of facility footprint $(-3 \%)$ and FCI costs (+3\%) when comparing the results provided by eXmoor Pharma Concepts and those generated using the detailed framework for FCI and facility footprint estimation. The small difference in facility footprint can be explained by differences in ratios used to compute the total facility footprint (shown in Table 3).

The key factors causing differences in the FCI predictions are the QC equipment costs and EMS costs. The difference in QC equipment costs is attributed to the fact that the list of QC equipment included in the FCI model (Supplementary Table 1) includes additional equipment that was not included in the analysis carried out by eXmoor Pharma Concepts. Moreover, in the FCI model, it was assumed that a single environmental monitoring probe per measurement (humidity, pressure and temperature) is required in each manufacturing suite. This may not always be the case. Hence, the difference in EMS costs can be attributed to differences in the number of environment monitoring probes considered. 


\subsection{Technology-specific trends in facility footprint and FCI}

As previously highlighted, there are a number of technologies available on the market for the commercial scale manufacture of cell therapy products. These technologies have different features therefore, when selecting a platform for cell therapy manufacture, it is important to understand the effect that this may have on the FCI and facility footprint. The effect of manufacturing platform selection on the relationship between FCI and facility footprint of cell therapy facilities with increasing demand was investigated in Figure 3. Figure 3a shows that autologous processes require higher footprints than allogeneic processes. This is an expected trend since autologous products require a scale-out manufacturing model as samples from different patients cannot be mixed. Allogeneic processes on the other hand benefit from the use of a scale-up approach to product manufacture, thus rapidly decreasing the facility footprint.

Figure 3a also indicates that for allogenic cell therapies, the manufacturing platform with the highest footprint is the multilayer flasks followed by the hollow fibre bioreactor. The manufacturing platform with the lowest facility footprint alternates between the multi-plate bioreactor and the stirred tank bioreactor depending on the commercialisation scenario.

Multilayer flasks have the highest footprint across all manufacturing platforms. This is due to the fact that specific incubators (INC40) and automation (AMLFM) are employed for incubation and manipulation of larger multilayer flasks. These technologies have relatively high footprints (INC40: $2.3 \mathrm{~m}^{2}$; AMLFM: $2.9 \mathrm{~m}^{2}$ ), thus, increasing the facility footprint for processes employing multilayer flasks.

Hollow fibre bioreactors have the second highest footprint across all platforms for allogeneic cell therapy manufacture featured in this article. Given the dose size selected for this study (100M cells), a single hollow fibre bioreactor is capable of producing 5 doses per batch. As the annual demand moves from 500 to 10,000 doses per year, the batch size increases from 25 to 
500 doses, increasing the number of hollow fibre bioreactors in parallel and hence increasing facility footprint.

The manufacturing platform with the lowest footprint alternates between the multi-plate bioreactor and the stirred tank bioreactor. A single multi-plate bioreactor has a lower footprint than a stirred tank bioreactor (Table 5) and is able to process up to 64 doses of $100 \mathrm{M}$ cells. Therefore, at smaller annual demands, where a single multi-plate bioreactor is required per batch, this platform offers a lower facility footprint than stirred tank bioreactors. As the annual demand increases to 10,000 doses, multiple multi-plate bioreactors are required in parallel to meet the batch size of 500 doses. As a single stirred tank bioreactor can manufacture up to 2,898 doses per batch (Table 5), these become the platform with the lowest facility footprint.

Figure 3a also demonstrates that for autologous manufacturing platforms, multilayer flasks are again the manufacturing platform with the highest facility footprint, followed by the rocking motion bioreactor, the static suspension bags and the integrated USP/DSP platform. As autologous processes operate at a relatively small scale, automated manipulator and large incubators are not used in combination with multilayer flasks. The relatively high facility footprint seen for these cell culture vessels in autologous processing is attributed to the use of biosafety cabinets (BSCs) required for open processing.

The rocking motion bioreactor has the second highest footprint. This is caused by two factors: 1) a rocking motion platform is required per batch and 2) incubators are used during the precell culture steps as these are carried out in static suspension bags (SSBs) as described in Pereira Chilima et al [64]. In the static suspension bags manufacturing platform, no dedicated equipment is required as all equipment used is shared across different batches manufactured in parallel, reducing the facility footprint. When using the integrated USP/DSP platform, a 
dedicated platform is also required per batch. However, this is an "all-in-one” platform, with relatively low footprint (Table 5).

Figure 3b highlights that similarly to the trends seen for facility footprint, FCI is higher for autologous processes versus allogeneic processes. However, the manufacturing platforms rank differently in FCI and facility footprint. Figure $\mathbf{3 b}$ shows that the allogeneic manufacturing platform with the highest FCI is the hollow fibre bioreactor followed by multilayer flasks, and that the platform with the lowest FCI alternates between multi-plate bioreactor and the stirred tank bioreactor.

The hollow fibre bioreactor has the highest FCI due to a combination of poor scalability and relatively high equipment costs $(\$ 150,000 /$ unit) (Table 5). Multilayer flasks have the second highest FCI due to the requirement of INC40s and AMLFMs. These technologies not only have high equipment costs (INC40 $=\$ 198,016 ;$ AMLFM $=\$ 482,560)$, but also increase the facility footprint (as seen in Figure 3a), increasing the building shell and fit-out costs as well as land and yard improvements costs.

Similar trends are seen in the ranking for FCI and facility footprint for stirred tank bioreactors and multi-plate bioreactors, where at lower annual demands multi-plate bioreactors have the lowest FCI. As the annual demand increases, increasing the number of multi-plate bioreactors per batch, stirred-tank bioreactors become the manufacturing platform with the lowest FCI.

As for autologous platforms, Figure $3 \mathbf{b}$ shows that multilayer flasks have the highest FCI followed by the integrated USP/DSP platform, rocking motion bioreactor and static suspension bags. Multilayer flasks have the highest FCI due to the use of BSCs in Grade B cleanrooms, which causes all cleanroom-dependent costs (e.g. building shell costs, fit-out costs etc.) to increase. The integrated USP/DSP platform has relatively high FCI due to fact that a dedicated platform with relatively high equipment costs (\$235,500/unit) is required per batch. 
Despite the fact that the rocking motion bioreactor was shown to be the platform for autologous cell therapy manufacture with the second highest facility footprint (Figure 3a), the equipment costs associated with the platform are relatively low, allowing this platform to have the second lowest FCI. Moreover, static suspension bags have the lowest FCI due to the fact that these only required shared equipment with relatively low costs.

\subsection{Relationship between FCI and facility footprint in cell therapy facilities}

Figure 3 has revealed that cell therapy facilities using different manufacturing platforms have different facility footprints and FCI. This section will establish the relationship between facility footprint and FCI across multiple manufacturing platforms in order to draw general relationships between FCI, facility footprint and technology selection.

Figure 4a shows a linear relationship between FCI and facility footprint across all manufacturing platforms. However, the slope of this relationship changes significantly across manufacturing platforms, indicating that some manufacturing platforms have higher FCI per $\mathrm{m}^{2}$ of facility footprint than others. In allogeneic facilities, this slope ranges between 7,000 $\$ / \mathrm{m}^{2}$ (multilayer flasks) to $13,000 \$ / \mathrm{m}^{2}$ (hollow fibre bioreactor). Similarly, in autologous facilities, FCI per $\mathrm{m}^{2}$ ranges between $8,200 \$ / \mathrm{m}^{2}$ (multilayer flasks) to $16,000 \$ / \mathrm{m}^{2}$ (integrated USP/DSP platforms). For the allogeneic processes, the manufacturing platform with the highest FCI per $\mathrm{m}^{2}$ is the hollow fibre bioreactor platform $\left(13,000 \$ / \mathrm{m}^{2}\right)$ followed by the multiplate bioreactor platform $\left(9,500 \$ / \mathrm{m}^{2}\right)$, the stirred tank bioreactor platform $\left(8,000 \$ / \mathrm{m}^{2}\right)$ and finally the multilayer flasks platform $\left(7,500 \$ / \mathrm{m}^{2}\right)$.

Hollow fibre bioreactors have a relatively high FCI per $\mathrm{m}^{2}$ due the combination of low capacity and high equipment costs as previously explained. Although both multi-plate bioreactors and stirred tank bioreactors have relatively low FCI (Figure 3b), these platforms also have low facility footprints increasing the FCI: facility footprint ratio. Moreover, even though the 
multilayer flasks have the second highest FCI across all platforms for allogeneic cell therapy manufacture (Figure 3b), this platform has significantly high facility footprint (Figure 3a), decreasing the FCI: facility footprint ratio.

For autologous processes, Figure 4a shows that the manufacturing platform with the highest FCI per $\mathrm{m}^{2}$ is the integrated USP/DSP platform $\left(15,000 \$ / \mathrm{m}^{2}\right)$ followed by the rocking motion bioreactor $\left(8,500 \$ / \mathrm{m}^{2}\right)$, the static suspension bag $\left(8,400 \$ / \mathrm{m}^{2}\right)$ and finally the multilayer flasks platform $\left(8,300 \$ / \mathrm{m}^{2}\right)$. The relatively high FCI per $\mathrm{m}^{2}$ seen when using the integrated USP/DSP platform is attributed to high equipment costs previously highlighted. Rocking motion bioreactor and static suspension bags offer lower FCI per $\mathrm{m}^{2}$ due relatively low FCI associated with this platforms. Similar to the trends seen for allogeneic processes, even though multilayer flasks have the highest FCI (Figure 3b), they also have the highest facility footprint across all manufacturing platforms for autologous cell therapy manufacture considered in this article, which reduced the FCI per $\mathrm{m}^{2}$.

Figure $\mathbf{4 b}$ shows the relationship between FCI per $\mathrm{m}^{2}$ of facility and facility footprint. This figure shows that for allogeneic processes, FCI per $\mathrm{m}^{2}$ decreases with increasing facility footprint across all manufacturing platforms but for autologous processes, this ratio remains constant. This is due to the economies of scale achieved in allogeneic processes as a result of a scale-up approach to cell therapy manufacture which allows for fixed overhead costs (e.g. EMS and QC costs) to be spread over a higher number of doses.

\subsection{Key factors influencing FCI and footprint of cell therapy facilities}

As previously mentioned, the layout of cell therapy facilities is likely to differ from traditional biotechnology. This section highlights the key features of the facility layout of cell therapy facilities and identifies the major factors contributing to FCI. Figure 5 illustrates the relationship between the different sections within the product manufacture floor of a cell 
therapy facility, by showing the detailed facility floorplan used as the basis to evaluate the ratios provided in Table 3. Even though the plant area is not shown in Figure $\mathbf{5}$ since it was assumed to be in a different floor, this is the section within the facility with the highest footprint. The section with the second highest footprint is the office space, this is also not clear from Figure 5, as this space was split across two different levels.

Figure 6 shows that the cost drivers affecting the FCI vary across the different manufacturing platforms. For allogeneic processes, when the annual demand is of 500 doses per year, the key direct cost drivers across most manufacturing platforms are building fit-out costs followed by process equipment costs and QC equipment costs. The effect of the core equipment costs on the hollow fibre bioreactor is higher than for other manufacturing platforms due to a combination of high equipment costs and low capacity as previously discussed. As the annual demand increases to 10,000 doses, economies of scale allow for overhead costs (EMS and QC costs) to be spread over a higher number of batches, reducing the relative contribution of these costs.

In autologous processes at 500 doses per year, for most manufacturing platforms, the building fit-out costs are the key direct cost driver followed by process equipment costs and the facility shell costs. This trend excludes the integrated USP/DSP platform due to the significantly higher core equipment costs associated with this platform. Increasing the annual demand to 10,000 has no significant effect on these trends due to the scale-out approach applied in autologous cell therapy manufacture.

\subsection{Evaluating costs and area factors}

Figure 3 and Figure 4 have shown that different manufacturing platforms require very different facility footprints and FCI and that the relationship between FCI and facility footprint 
may vary with annual demand. Therefore, costs and area factors were derived in order to provide short-cut methods to evaluate footprint and FCI for bespoke cell therapy facilities. This is shown in Figure 7. A detailed breakdown of the different factors contributing to the overall cost factor across the different manufacturing platforms can be found in Table 6.

Figure 7a shows an inverse relationship between the cost factors and the area factors where manufacturing platforms with the highest area factors (i.e. highest core equipment costs per $\mathrm{m}^{2}$ ) (e.g. hollow fibre bioreactors and integrated USP/DSP platforms) have the lowest cost factors (i.e. lowest ratio between FCI and core equipment costs) and vice versa. This figure also shows that annual demand has an impact on FCI and facility footprint of allogeneic processes but not on autologous processes due to the economies of scale achieved with allogeneic processes as previously discussed. Moreover, Figure 7a shows that for allogenic processes, area factors range between 950 (stirred tank bioreactor) and 5,400 (hollow fibre bioreactor) and cost factors range from 2.3 (hollow fibre bioreactor) and 8.3 (stirred tank bioreactor). Similar trends are seen for autologous processes as area factors range between 980 (multilayer flasks) and 6,500 (integrated USP/DSP platform) and cost factors vary from 2.3 (integrated USP/DSP platform) and 8.5 (multilayer flasks).

As Figure 7a highlighted that the cost and area factors are sensitive to annual demand in allogeneic processes, Figure $\mathbf{7 b}$ was generated to illustrate the process of selecting the adequate cost and area factor from Figure 7a taking into account the manufacturing platform used and the target annual demand.

\subsection{Selecting a project-specific cost factor for cell therapy facilities}

The hypothetical facilities considered in this case study so far were assumed to be built on a greenfield site. However, the starting condition of the site chosen to build the facility may vary from project to project. Some projects may be built on a brownfield site and others in an 
existing building shell. Moreover, the geographical location of the facility will also have an effect on the FCI. Furthermore, different manufacturing platforms require the use of different cost factors for relevant evaluating of FCI as previously observed (Figure 3 and Figure 4). Hence, it is important to provide cost factors that capture project-specific features in order to increase the accuracy of estimates. The differences in cost factor across the manufacturing platforms were captured by grouping them together into three categories according to the core equipment costs per $\mathrm{m}^{2}$ characteristic of the different platforms. These categories were: high equipment costs per $\mathrm{m}^{2}$ of facility, medium equipment costs per $\mathrm{m}^{2}$ of facility and low equipment costs per $\mathrm{m}^{2}$ of facility.

The different platforms were grouped together according to the trends seen for area factors in Figure 7a. The hollow fibre bioreactor and integrated USP/DSP platforms were considered to have relatively high equipment costs per $\mathrm{m}^{2}$. Platforms with medium equipment costs per $\mathrm{m}^{2}$ of facility were assumed to be the multilayer flasks (allogeneic), multi-plate bioreactor, static suspension bags and rocking motion bioreactor. Manufacturing platforms with low equipment costs per $\mathrm{m}^{2}$ of facility were assumed to be stirred tank bioreactor and the multilayer flask with open steps (autologous).

The effect of manufacturing platform selection, the starting condition of the construction site and its geographical location and manufacturing platform selection are captured in Figure 8. For each site condition-geographic region combination, each group of manufacturing platforms seen in Figure 8 offers a range of cost factors in order to account for the effect of annual demand on the cost factor; such that at smaller annual demands, users may choose higher cost factors and vice-versa.

Figure 8 shows that manufacturing platforms with high equipment costs per $\mathrm{m}^{2}$ have average cost factors of 2.1-3.3 depending on the annual demand, geographic region and initial condition 
of the construction site. This factor increases to 4-6.4 for platforms with medium equipment costs per $\mathrm{m}^{2}$ and 6.4-10.1 for platforms with low equipment costs per $\mathrm{m}^{2}$. Moreover, Figure 8 shows also that in low economically developed areas such as India and Mexico, the cost factors are lower as building materials, land and labour costs are lower. As the degree of economic development increases to geographic areas such as the US west coast or Eastern Europe, these costs increase, increasing the overall cost factor. Furthermore, when building a facility in the brownfield site as opposed to a greenfield site, it was assumed that no yard improvements were required such that these costs would be null, decreasing the overall project costs and hence the cost factor. This assumption may not always apply as in some cases land remediation maybe required due to possible soil contamination, which will incur some yard improvement costs. Moreover, when considering building the facility in an existing (rented) shell, although the land costs, yard improvement costs and shell costs maybe null, resulting in lower FCI, and hence a lower cost factor, the facility running costs would be higher as the company now must pay to rent the facility. Furthermore, when using an existing shell possible design restrictions must also be considered.

\section{Conclusion}

This article aimed at proposing a detailed project-specific factorial methodology and using it to provide benchmark short-cut ratios for FCI and facility footprint evaluation for cell therapy facilities using the core equipment costs. The results clearly highlight that allogenic facilities have significantly lower FCI and facility footprint than autologous facilities. Moreover, when evaluating FCI and facility trends for different cell therapy facilities, the results showed that multiple factors will have an effect on the FCI and footprint of cell therapy facilities including annual demand, manufacturing technology, initial condition of the construction site and geographic location of the facility. These parameters caused the area factors to range between

675-6,815 and the cost factors to range between 2.3 and 8.5 . 
FCI and facility footprint are important factors to consider when selecting a manufacturing strategy for a novel cell therapy product. This method can be used for manufacturing platform selection based on crude FCI and facility footprint estimates during the early stages of process development of novel cell therapy products.

\section{Acknowledgements}

Financial support from the UK Engineering and Physical Sciences Research Council (EPSRC) and Pall Life Sciences is gratefully acknowledged (Grant Code: EP/G034656/1). Andrew Besso, Paul Dempsey and Angela Osborne at eXmoor Pharma Concepts (Bristol, UK), a design consultancy firm, are gratefully acknowledged for providing capital investment and facility footprint estimations to help validate the proposed methodology as well as generating the facility layout diagram in Figure 5. The Advanced Centre for Biochemical Engineering at UCL hosts the Future Targeted Healthcare Manufacturing Hub in collaboration with UK universities and with funding from the EPSRC and a consortium of industry and government users. 


\section{References}

[1] J. Glenn and K. Whartenby, "Mesenchymal stem cells: Emerging mechanisms of immunomodulation and therapy.," World J. Stem Cells, vol. 6, no. 5, pp. 526-39, Nov. 2014.

[2] M. Reinders et al., "Autologous bone marrow-derived mesenchymal stromal cells for the treatment of allograft rejection after renal transplantation: results of a phase I study.," Stem Cells Transl. Med., vol. 2, no. 2, pp. 107-11, Feb. 2013.

[3] W. Noort et al., "Mesenchymal stromal cells to treat cardiovascular disease: strategies to improve survival and therapeutic results.," Panminerva Med., vol. 52, no. 1, pp. 2740, Mar. 2010.

[4] L. Wang, I. Tran, K. Seshareddy, M. Weiss, and M. Detamore, “A Comparison of Human Bone Marrow-Derived Mesenchymal Stem Cells and Human Umbilical CordDerived Mesenchymal Stromal Cells for Cartilage Tissue Engineering,” Tissue Eng. Part A, vol. 15, no. 8, pp. 2259-2266, Aug. 2009.

[5] A. Ramkisoensing et al., "Human Embryonic and Fetal Mesenchymal Stem Cells Differentiate toward Three Different Cardiac Lineages in Contrast to Their Adult Counterparts,” PLoS One, vol. 6, no. 9, p. e24164, Sep. 2011.

[6] M. Chmielewski, A. Hombach, and H. Abken, "Antigen-specific T-cell activation independently of the MHC: Chimeric antigen receptor-redirected T cells," Front. Immunol., vol. 4, no. NOV, pp. 1-7, 2013.

[7] B. Tumaini et al., "Simplified process for the production of anti-CD19-CARengineered T cells,” Cytotherapy, vol. 15, no. 11, pp. 1406-1415, Nov. 2013.

[8] M. Cartellieri et al., "A novel Ex Vivo isolation and expansion procedure for chimeric antigen receptor engrafted human T cells,” PLoS One, vol. 9, no. 4, pp. 1-12, 2014.

[9] V. Hillerdal, M. Ramachandran, J. Leja, and M. Essand, "Systemic treatment with CARengineered $\mathrm{T}$ cells against PSCA delays subcutaneous tumor growth and prolongs survival of mice.," BMC Cancer, vol. 14, p. 30, 2014.

[10] Reuters, "Novartis, Juno face production hurdles for new blood cancer drugs | Reuters," 2015. [Online]. Available: http://in.reuters.com/article/us-pharmaceuticals-cancerfactories-anal-idINKCN0SO0F520151030F520151030. [Accessed: 24-Dec-2016].

[11] S. Rosenberg and N. Restifo, "Adoptive cell transfer as personalized immunotherapy for human cancer,” Science (80-. )., vol. 348, no. 6230, pp. 62-68, 2015.

[12] C. Sumen, D. Williams, and G. Binder-Scholl, “Adoptive T-cell therapies: Unlocking the potential of engineered antigen receptors,” Drug Discov. world, vol. 16, no. 2, pp. 47-54, 2015.

[13] M. Bernardo et al., "Mesenchymal Stromal Cells: Sensors and Switchers of Inflammation,” Cell Stem Cell, vol. 13, no. 4, pp. 392-402, Oct. 2013.

[14] J. Valton et al., "A Multidrug-resistant Engineered CAR T Cell for Allogeneic Combination Immunotherapy.,” Mol. Ther., vol. 23, no. 9, pp. 1507-18, 2015.

[15] A. Bartholomew et al., "Mesenchymal stem cells suppress lymphocyte proliferation in vitro and prolong skin graft survival in vivo," Exp. Hematol., vol. 30, no. 1, pp. 42-48, 2002.

[16] H. Sheng et al., "A critical role of IFN $\gamma$ in priming MSC-mediated suppression of T cell proliferation through up-regulation of B7-H1,” Cell Res., vol. 18, no. 8, pp. 846-857, Aug. 2008.

[17] M. Di Nicola et al., "Human bone marrow stromal cells suppress T-lymphocyte proliferation induced by cellular or nonspecific mitogenic stimuli,” Blood, vol. 99, no. 10, 2002.

[18] M. González, E. Gonzalez-Rey, L. Rico, D. Büscher, and M. Delgado, "Treatment of experimental arthritis by inducing immune tolerance with human adipose-derived 
mesenchymal stem cells,” Arthritis Rheum., vol. 60, no. 4, pp. 1006-1019, Apr. 2009.

[19] I. Kan et al., "Dopaminergic differentiation of human mesenchymal stem cellsUtilization of bioassay for tyrosine hydroxylase expression,” Neurosci. Lett., vol. 419, no. 1, pp. 28-33, 2007.

[20] J. Hare et al., "A Randomized, Double-Blind, Placebo-Controlled, Dose-Escalation Study of Intravenous Adult Human Mesenchymal Stem Cells (Prochymal) After Acute Myocardial Infarction,” JAC, vol. 54, pp. 2277-2286, 2009.

[21] M. Naghdi, T. Tiraihi, S. Namin, and J. Arabkheradmand, “Transdifferentiation of bone marrow stromal cells into cholinergic neuronal phenotype: a potential source for cell therapy in spinal cord injury,” Cytotherapy, vol. 11, no. 2, pp. 137-152, Jan. 2009.

[22] J. Pattasseril, H. Varadaraju, L. Lock, and J. Rowley, "Downstream Technology Landscape for Large-Scale Therapeutic Cell Processing,” Suppl. 38 BioProcess Int., vol. 11, no. 3, 2013.

[23] D. Stroncek, J. Jin, V. David-Ocampo, V. Fellowes, L. Moses, and M. Sabatino, "Production of Clinical T Cell Therapies," Springer International Publishing, 2015, pp. 129-150.

[24] P. Ascierto, D. Stroncek, and E. Wang, Developments in T cell based cancer immunotherapies. 2015.

[25] R. Somerville and M. Dudley, “Bioreactors get personal.,” Oncoimmunology, vol. 1, no. 8, pp. 1435-1437, 2012.

[26] A. Kaiser et al., "Towards a commercial process for the manufacture of genetically modified T cells for therapy.," Cancer Gene Ther., vol. 22, no. 2, pp. 72-8, 2015.

[27] A. Kaiser, M. Assnmacher, and I. Johnston, "METHOD FOR AUTOMATED GENERATION OF GENETICALLY MODIFIED T CELLS,” 2015.

[28] C. Lamers, R. Willemsen, B. Luider, R. Debets, and R. Bolhuis, "Protocol for gene transduction and expansion of human T lymphocytes for clinical immunogene therapy of cancer.," Cancer Gene Ther., vol. 9, no. 7, pp. 613-23, 2002.

[29] M. Granzin et al., "Fully automated expansion and activation of clinical-grade natural killer cells for adoptive immunotherapy,” Cytotherapy, vol. 17, no. 5, pp. 621-632, May 2015.

[30] J. Rowley, E. Abraham, A. Campbell, H. Brandwein, and S. Oh, "Meeting lot-size challenges of manufacturing adherent cells for therapy,” Bioprocess Int., vol. 10, no. SUPPL. 3, pp. 16-22, 2012.

[31] L. Lambert et al., "Improving T Cell Expansion with a Soft Touch," Am. Chem. Soc., vol. 17, pp. 821-826, 2017.

[32] T. Pereira Chilima, T. Bovy, and S. Farid, "Designing the Optimal Manufacturing Strategy for an Adherent Allogeneic Cell Therapy,” Bioprocess int, vol. 14, no. 9, pp. 24-32, 2016.

[33] J.-F. Michiels and M. Egloff, “Scaling Up Stem Cells,” GEN Mag. , vol. 33, no. 2, 2013.

[34] M. Szczypka, D. Splan, H. Woolls, and H. Brandwein, "Single-Use Bioreactors and Microcarriers Scalable Technology for Cell-Based Therapies,” 54 BioProcess Int., vol. 12, no. 3, 2014.

[35] J. Castillo, "Indutrialization of Stem Cell Processes - how to identify the right strategy ?," in ISCT, 2014.

[36] J. Jin et al., "Simplified Method of the Growth of Human Tumor Infiltrating Lymphocytes in Gas-permeable Flasks to Numbers Needed for Patient Treatment,” $J$. Immunother., vol. 35, no. 3, pp. 283-292, Apr. 2012.

[37] Coulson and Richardson, Coulson \& Richardsons Chemical Engineering Design, vol. 6, no. 4. ELSEVIER, 2005.

[38] M. Peters and K. Timmerhaus, PLANT DESIGN AND ECONOMICS FOR CHEMICAL 
ENGINEERS, 4th ed. 1991.

[39] R. Pavlotsky, “Approximating facilities costs,” Solid State Technology, 2004. [Online]. Available: $\quad$ http://electroiq.com/blog/2004/08/approximating-facilities-costs/. [Accessed: 28-Feb-2017].

[40] J. Novais, N. Titchener-Hooker, and M. Hoare, "Economic comparison between conventional and disposables-based technology for the production of biopharmaceuticals,” Biotechnol. Bioeng., vol. 75, no. 2, pp. 143-153, 2001.

[41] D. Brennan and K. Golonka, "Evolving Process Designs," vol. 80, no. September, 2002.

[42] D. Petrides, R. Harrison, P. Todd, S. Rudge, and D. Petrides, "Bioprocess Design and Economics Bioseparations Science and Engineering (2 nd Edition),” 2015.

[43] A. Sinclair and M. Monge, "Concept Facility Based on Single-Use Systems, Part 2: Leading the Way for Biomanufacturing in the 21st Century," Bioprocess Interntational, pp. 51-55, 2005.

[44] K. Kinsella and S. Dewan, "SINGLE-USE MARKET - Rise of Single-Use Technologies \&amp; Systems in Biopharmaceuticals | Articles | drug development and delivery back issues | Drug Development \&amp; Delivery,” Drug Development \& Delivery, 2015. [Online]. Available: http://www.drug-dev.com/Main/Back-Issues/SINGLEUSEMARKET-Rise-of-SingleUse-Technologies-Sy-1022.aspx. [Accessed: 25-Feb-2017].

[45] A. Lopes, "Single-use in the biopharmaceutical industry: A review of current technology impact, challenges and limitations," Food Bioprod. Process., vol. 93, pp. 98-114, 2015.

[46] B. Barak and B. Bader, "Lifecycle Cost Analysis for Single-Use Systems," Biopharm International, Nov-2008.

[47] W. Flaherty and P. Perrone, "Environmental and Financial Benefits of Single-Use Technology,” 2012.

[48] R. Jacquemart, M. Vandersluis, M. Zhao, K. Sukhija, N. Sidhu, and J. Stout, "A Singleuse Strategy to Enable Manufacturing of Affordable Biologics," Comput. Struct. Biotechnol., vol. 14, pp. 309-318, 2016.

[49] J. Pollock, S. Ho, and S. Farid, "Fed-batch and perfusion culture processes: Economic, environmental, and operational feasibility under uncertainty,” Biotechnol. Bioeng., vol. 110, no. 1, pp. 206-219, Jan. 2013.

[50] A. Rayner, "The application of disposable single use equipment, and it's impact on biopharma plat design.” 2010.

[51] B. Sargent, "Single-use stirred bioreactors: Enabling flexible biomanufacturing," cell dish Cult., Sep. 2013.

[52] A. Shukla and U. Gottschalk, "Single-use disposable technologies for biopharmaceutical manufacturing," Trends Biotechnol., vol. 31, no. 3, pp. 147-154, 2013.

[53] G. Tiene, "Single-Use Now Key Technology in Biopharmaceutical Manufacturing | Pharmaceutical Outsourcing - The Journal of Pharmaceutical \&amp; Biopharmaceutical Contract Services,” Pharmaceutical outsourcing, 2016. [Online]. Available: http://www.pharmoutsourcing.com/Featured-Articles/182579-Single-Use-Now-KeyTechnology-in-Biopharmaceutical-Manufacturing/. [Accessed: 22-Feb-2017].

[54] P. Rogge, D. Müller, and S. Schmidt, "The Single-Use or Stainless Steel Decision Process: A CDMO Perspective -,” Bioprocess International, Dec-2015.

[55] S. Haigney, “Integrating Single-Use Systems in Pharma Manufacturing," PharmaTech.com, vol. 40, no. 6, pp. 42-44, 2016.

[56] A. Geipel-Kern, "Single-Use Technologies in Biomanufacturing,” Bioprocess world, 2009. [Online]. Available: http://www.process-worldwide.com/single-usetechnologies-in-biomanufacturing-a-302185/. [Accessed: 25-Feb-2017].

[57] S. Cox, J. Lim, L. Leveen, A. Sinclair, and M. Monge, "The Environmental Impact of Disposable Technologies,” BioPharm Int., 2008. 
[58] N. Guldager, "Next-Generation Facilities for Monoclonal Antibody Production," Pharmatech.com, vol. 33, no. 7, 2009.

[59] H. Levine, J. Lilja, R. Stock, H. Hummel, and S. Jones, "Efficient, Flexible Facilities for the 21st Century,” Suppl. 2 BioProcess Int., vol. 10, no. 11, 2012.

[60] E. Langer and R. Rader, "Single-use technologies in biopharmaceutical manufacturing: A 10-year review of trends and the future," Eng. Life Sci., vol. 14, no. 3, pp. 238-243, May 2014.

[61] J. Castillo, "Industrialization of Stem Cell Processes: how to identify the right strategy?,” 2013.

[62] A. Simaria et al., "Allogeneic cell therapy bioprocess economics and optimization: Single-use cell expansion technologies,” Biotechnol. Bioeng., vol. 111, no. 1, pp. 6983, 2014.

[63] T. D. Pereira Chilima, F. Moncaubeig, and S. S. Farid, "Impact of allogeneic stem cell manufacturing decisions on cost of goods, process robustness and reimbursement," Biochem. Eng. J., vol. 137, pp. 132-151, Sep. 2018.

[64] T. Pereira Chilima, F. Moncaubeig, and S. Farid, "Cost effective manufacturing strategies for feasible commercialisation of CAR T-cell products," in ECI Scale-up and Manufacturing of Cell-based Therapies V, 2017.

[65] A. Simaria et al., "Allogeneic cell therapy bioprocess economics and optimization: Single-use cell expansion technologies,” Biotechnol. Bioeng., vol. 111, no. 1, pp. 6983, Jan. 2014.

[66] J. Pattasseril, H. Varadaraju, L. Lock, and J. Rowley, "Downstream technology landscape for large-scale therapeutic cell processing," Bioprocess Int., vol. 11, no. SUPPL. 3, pp. 38-47, 2013.

[67] M. Diogo, C. da Silva Lobato, and J. Cabral, "Separation technologies for stem cell bioprocessing,” Biotechnol. Bioeng., vol. 109, no. 11, pp. 2699-2709, 2012.

[68] X. Wang and I. Rivière, "Clinical manufacturing of CAR T cells: foundation of a promising therapy,” Mol. Ther. - Oncolytics, vol. 3, 2016.

[69] B. Levine, "Performance-enhancing drugs: design and production of redirected chimeric antigen receptor (CAR) T cells,” Cancer Gene Ther., vol. 22, no. 2, pp. 79-84, Mar. 2015.

[70] C. Wegener, C. Heber, and K. Min, "Novel cell washing device using spinning membrane filtration," Cytotherapy, vol. 15, no. 4, p. S27, Apr. 2013.

[71] S. Hassan, A. Simaria, H. Varadaraju, S. Gupta, K. Warren, and S. Farid, "Allogeneic cell therapy bioprocess economics and optimization: downstream processing decisions," Regen. Med., vol. 10, no. 5, pp. 591-609, Aug. 2015.

[72] Rontis medical, “COBE 2991 Cell Processor | Rontis Medical.” [Online]. Available: http://rontismedical.com/cobe-2991-cell-processor/. [Accessed: 24-Dec-2016].

[73] A. Dragani, A. Angelini, A. Iacone, D. D’Antonio, and G. Torlontano, "Comparison of five methods for concentrating progenitor cells in human marrow transplantation,” Blut, vol. 60, no. 5, pp. 278-281, May 1990.

[74] Haemonetics, "Cell saver 5+ Standard of care in intraoperative autotransfusion."

[75] C. Serrick and M. Scholz, "Partial bowls using the Haemonetics Cell Saver 5: does it produce a quality product?,” J. Extra. Corpor. Technol., vol. 37, no. 2, pp. 161-4, Jun. 2005.

[76] D. Powell, A. Brennan, Z. Zheng, H. Huynh, J. Cotte, and B. Levine, “Efficient clinicalscale enrichment of lymphocytes for use in adoptive immunotherapy using a modified counterflow centrifugal elutriation program,” Cytotherapy, vol. 11, no. 7, pp. 923-935, 2009.

[77] M. Apel et al., "Integrated clinical scale manufacturing system for cellular products 
derived by magnetic cell separation, centrifugation and cell culture,” Chemie-IngenieurTechnik, vol. 85, no. 1-2, pp. 103-110, 2013.

[78] Octane, "“see How' Octane technology can impact your goals."

[79] H. Lang, "Simplified Approach to Preliminary Cost Estimates,” Chem. Eng., vol. 55, pp. 112-113, 1948.

[80] R. Giancola, T. Bonfini, and A. Iacone, "Cell therapy: cGMP facilities and manufacturing.,” Muscles. Ligaments Tendons J., vol. 2, no. 3, pp. 243-7, Jul. 2012.

[81] A. Dietz, D. Padley, and D. Gastineau, "Infrastructure Development for Human Cell Therapy Translation,” Clin. Pharmacol. Ther., vol. 82, no. 3, pp. 320-324, Sep. 2007.

[82] J. Chester, "Isolators v. RABS: Isolators v. RABS: Facility Design Considerations for Facility Design Considerations for a Fill a Fill - -Finish Suite Finish Suite,” in APV Basle conference, 2008.

[83] W. Whitford, "Single-Use Systems As Principal Components in Bioproduction," Bioprocess Int., pp. 34-42, 2010.

[84] R. Eibl and D. Eibl, Single-Use Technology in Biopharmaceutical Manufacture. 2010.

[85] N. Guldager, “Cost advantages of single use technologies,” Pharm. Technol., 2010. 


\section{List of Tables}

Table 1 Examples of current cell therapy facilities

Table 2 Reported values for cleanroom costs (\$ per $\left.\mathrm{m}^{2}\right)$

Table 3 Ratio between the footprint of the different sections within a facility and the footprint of the product manufacture area

Table 4 Key case study assumptions

Table 5 Key characteristics of the manufacturing platforms included in this case study

Table 6 Cost factor breakdown for different hypothetical cell therapy facilities producing 5,000 doses of 100M cells per year

Supplementary Table 1 List of equipment required per QC lab and their unit costs 


\section{List of Figures}

Figure 1 Schematic representation of the detailed factorial methodology used for estimating a) facility footprint b) FCI evaluation.

Figure 2 Comparison between results attained using the novel factorial method for FCI and facility footprint evaluation and those provided by eXmoor Pharma Concepts for a) facility footprint and b) FCI. The scenario selected shown here corresponds to a greenfield project in a medium economically developed country.

Figure 3 a) Facility footprint and b) FCI with increasing annual demand for different manufacturing platforms. The unit operations included in the allogenic platforms were inoculation, cell culture and wash and volume reduction while the unit operations included in the autologous platforms were elutriation, cell wash, cell selection, cell activation, viral transduction, cell culture and wash and volume reduction. For allogenic processes a harvest density of 45,000 cells $/ \mathrm{m}^{2}$ for all platforms and surface area/L for microcarrier-based platforms of $5,540 \mathrm{~cm}^{2} / \mathrm{L}$ were assumed. For autologous processes a maximum cell density for cell culture was $7 \times 10^{6}$ cells $/ \mathrm{ml}$ was assumed. The scenario selected shown here corresponds to a greenfield project in a medium economically developed country. The abbreviations indicate the name of the different manufacturing platforms: MLF = multilayer flask; MPB = multi-plate bioreactor; HFB = hollow fibre bioreactor; STR = stirred tank bioreactor; MLF (open) = multilayer flask with open steps; SSB = static suspension bag; INT = integrated USP/DSP platform; RMB = rocking motion bioreactor.

Figure 4 Relationship between a) FCI and facility footprint and b) FCI per $\mathrm{m}^{2}$ of facility and facility footprint across multiple manufacturing platforms. The unit operations included in the allogenic platforms were inoculation, cell culture and wash and volume reduction while the unit operations included in the autologous platforms were elutriation, cell wash, cell selection, cell activation, viral transduction, cell culture and wash and volume reduction. For allogenic processes a harvest density of 45,000 cells $/ \mathrm{cm}^{2}$ for all platforms and surface area/L for microcarrier-based platforms of $5,540 \mathrm{~cm}^{2} / \mathrm{L}$ were assumed. For autologous processes a maximum cell density for cell culture was $7 \times 10^{6}$ cells $/ \mathrm{ml}$ was assumed. The scenario selected shown here corresponds to a greenfield project in a medium economically developed country. The abbreviations indicate the name of the different manufacturing platforms: MLF = multilayer flask; MPB = multi-plate bioreactor; HFB = hollow fibre bioreactor; STR = stirred tank bioreactor; MLF (open) = multilayer flask with open steps; SSB = static suspension bag; INT = integrated USP/DSP platform; RMB = rocking motion bioreactor.

Figure 5 General facility layout used in this analysis to determine the relative footprint of the different areas within a cell therapy facility. Yellow regions = Grade C area classification; Green regions $=$ Grade $\mathrm{D}$ area classification; white regions $=$ Grade $\mathrm{U}$ area classification . Diagram generated by eXmoor Pharma Concepts.

Figure 6 Contribution of the different factors towards the FCI for a dose size of $100 \mathrm{M}$ cells and annual demands of 500 and 10,000 doses per year. The scenario selected shown here corresponds to a greenfield project in a medium economically developed country. The abbreviations indicate the name of the different manufacturing platforms: MLF = multilayer flask; $\mathrm{MPB}=$ multi-plate bioreactor; $\mathrm{HFB}=$ hollow fibre bioreactor; STR $=$ stirred tank 
bioreactor; MLF (open) = multilayer flask with open steps; SSB = static suspension bag; INT = integrated USP/DSP platform; RMB = rocking motion bioreactor.

Figure 7 a) Trends in area factor and cost factor across multiple manufacturing platforms and commercialisation demand scenarios for a product with a dose size of $100 \mathrm{M}$ cells. The unit operations included in the allogenic platforms were inoculation, cell culture and wash and volume reduction while the unit operations included in the autologous platforms were elutriation, cell wash, cell selection, cell activation, viral transduction, cell culture and wash and volume reduction. For allogenic processes a harvest density of $45,000 \mathrm{cells} / \mathrm{m}^{2}$ for all platforms and surface area/L for microcarrier-based platforms of $5,540 \mathrm{~cm}^{2} / \mathrm{L}$ were assumed. For autologous processes a maximum cell density for cell culture was $7 \times 10^{6}$ cells $/ \mathrm{ml}$ was assumed. The scenario selected shown here corresponds to a greenfield project in a medium economically developed country. The abbreviations indicate the name of the different manufacturing platforms: MLF = multilayer flask; $\mathrm{MPB}=$ multi-plate bioreactor; $\mathrm{HFB}=$ hollow fibre bioreactor; STR = stirred tank bioreactor; MLF (open) = multilayer flask with open steps; SSB = static suspension bag; INT = integrated USP/DSP platform; RMB = rocking motion bioreactor $\mathbf{b})$ Method for evaluating facility footprint and FCI.

Figure 8 Change in cost factor with initial condition of the facility site, manufacturing platform and geographic location of the facility. The manufacturing platforms with high costs $/ \mathrm{m}^{2}$ are the hollow fibre bioreactor and the integrated USP/DSP. The manufacturing platforms with medium costs $/ \mathrm{m}^{2}$ are the multilayer flasks, multi-plate bioreactor, static suspension bags and rocking motion bioreactor and the manufacturing platform with low costs $/ \mathrm{m}^{2}$ are the stirred tank bioreactor and multilayer flasks with open steps. 
Table 1 Examples of current cell therapy facilities

\begin{tabular}{|c|c|c|c|c|c|}
\hline Company & Location & $\begin{array}{l}\text { Cost } \\
\text { \$(M) }\end{array}$ & $\begin{array}{l}\text { Total } \\
\text { size } \\
\left(\mathbf{m}^{2}\right)\end{array}$ & Build/Purchase & Details \\
\hline Argos Therapeutics [1], [2] & Durham, NC, USA & 57 & 9,290 & Build & $\begin{array}{l}\text { Support automated } \\
\text { production of } \\
\text { personalized } \\
\text { immunotherapy } \\
\text { product candidates }\end{array}$ \\
\hline $\begin{array}{l}\text { UC Davis/ California } \\
\text { Institute of Regen Med[3] }\end{array}$ & $\begin{array}{l}\text { Sacramento, CA, } \\
\text { USA }\end{array}$ & 62 & 8,361 & Build & $\begin{array}{l}\text { Includes research } \\
\text { and laboratory } \\
\text { facilities for } \\
\text { clinical trial } \\
\text { product } \\
\text { manufacture }\end{array}$ \\
\hline Bone Therapeutics[4], [5] & Gosselies, Belgium & 11 & 3,000 & Build & $\begin{array}{l}\text { Commercial scale } \\
\text { manufacture of cell } \\
\text { therapies targeted } \\
\text { at bone fractures }\end{array}$ \\
\hline $\begin{array}{l}\text { PharmaCell B.V. - } \\
\text { Advanced Therapies[6], } \\
\text { [7] }\end{array}$ & $\begin{array}{l}\text { Maastricht, } \\
\text { Netherlands }\end{array}$ & 6.34 & 1,440 & $\begin{array}{l}\text { Purchased from } \\
\text { TiGenix }\end{array}$ & $\begin{array}{l}\text { Manufacture of } \\
\text { ChrondoCelect }\end{array}$ \\
\hline Novartis [8],[9] & $\begin{array}{l}\text { New Jersey, NJ, } \\
\text { USA }\end{array}$ & 43 & 16,072 & $\begin{array}{l}\text { Purchased from } \\
\text { Dendreon }\end{array}$ & $\begin{array}{l}\text { Manufacture of } \\
\text { personalised } \\
\text { products from the } \\
\text { collaboration with } \\
\text { UPenn }\end{array}$ \\
\hline Kite Pharma[10],[11] & Netherlands & 21 & - & $\begin{array}{l}\text { Purchased from } \\
\text { T-Cell Factory } \\
\text { B.V }\end{array}$ & $\begin{array}{l}\text { Discovery and } \\
\text { development of } \\
\text { TCR products }\end{array}$ \\
\hline $\begin{array}{l}\text { Pluristem } \\
\text { Therapeutics[12],[13] }\end{array}$ & Haifa, Israel & 6.2 & - & Build & $\begin{array}{l}\text { Production of } \\
\text { placenta expanded } \\
\text { cells }\end{array}$ \\
\hline $\begin{array}{l}\text { Xcyte } \\
\text { Therapeutics[14],[15] }\end{array}$ & Bothell, WA, USA & 4 & 3,763 & Build & $\begin{array}{l}\text { Production of T- } \\
\text { cell products for } \\
\text { clinical trials }\end{array}$ \\
\hline $\begin{array}{l}\text { Aastrom } \\
\text { Biosciences[16],[17] }\end{array}$ & $\begin{array}{l}\text { Ann Arbor, MI, } \\
\text { USA }\end{array}$ & 1.4 & 2,787 & Build & $\begin{array}{l}\text { Production of } \\
\text { autologous } \\
\text { products for tissue } \\
\text { repair }\end{array}$ \\
\hline $\begin{array}{l}\text { Cardio } 3 \text { Biosciences (now } \\
\text { Celyad)[18] }\end{array}$ & $\begin{array}{l}\text { Minnesota, MN, } \\
\text { USA }\end{array}$ & 1.5 & 1,394 & Build & $\begin{array}{l}\text { Development of } \\
\text { autologous product } \\
\text { for heart failure }\end{array}$ \\
\hline $\begin{array}{l}\text { University of } \\
\text { Pennsylvania[19] }\end{array}$ & Pennsylvania, USA & 27 & 2,787 & Build & $\begin{array}{l}\text { Development of } \\
\text { personalised cancer } \\
\text { therapies }\end{array}$ \\
\hline Cell Medica[20] & London, UK & 4.59 & 1,080 & Build & $\begin{array}{l}\text { Personalised T-cell } \\
\text { products }\end{array}$ \\
\hline
\end{tabular}




$\begin{array}{llllll}\text { MaSTherCell[21],[22] } & \text { Brussels, Belgium } & 5.84 & 600 & \text { Build } & \begin{array}{l}\text { Contract } \\ \text { manufacturer }\end{array} \\ \text { Dendreon[23],[24] } & \text { Atlanta } & 80 & 18,580 & \text { Build } & \begin{array}{l}\text { Autologous } \\ \text { dendritic cells } \\ \text { manufacture }\end{array}\end{array}$

[1] J. DeBruyn, "Durham’s Argos Therapeutics, Inc. (Nasdaq: ARGS) expands cancer-fighting scope with new trial - Triangle Business Journal,” Triangle business journal, 2016. [Online]. Available: http://www.bizjournals.com/triangle/news/2016/03/24/durhamsargos-expands-cancer-fighting-scope-with.html. [Accessed: 16-Mar-2017].

[2] Argos therapeutics, "Argos Therapeutics Announces Plans for New Manufacturing Facility in Research Triangle Park Area in Durham, North Carolina,” sec.gov, 2014. [Online]. Available:

https://www.sec.gov/Archives/edgar/data/1105533/000117184314004610/newsrelease.htm. [Accessed: 16-Mar-2017].

[3] K. Robertson, “Stem cell research center to open at UCD med center - Sacramento Business Journal,” Sacramento Business Journal, 2010. [Online]. Available: http://www.bizjournals.com/sacramento/stories/2010/03/01/daily53.html. [Accessed: 16-Mar-2017] [4] Bone therapeutics, "Bone Therapeutics invests in cell therapy manufacturing facility," Bone therapeutics, 2013. [Online]. Available: http://www.bonetherapeutics.com/upload/files/20130225_Bone_Therapeutics_Press_Release.pdf. [Accessed: 16-Mar-2017]. [5] Flandersbio, "Bone Therapeutics officially opens its new headquarters in Gosselies | News | FlandersBio," FlandersBio, 2015. [Online]. Available: http://flandersbio.be/news/bone-therapeutics-officially-opens-its-new-headquarters-in-gosselies/. [Accessed: 16-Mar2017].

[6] Z. Brennan, "ImmunoCellular taps PharmaCell to manufacture dendritic cell-based vaccine for trial," Outsourcing Pharma, 2015. [Online]. Available: http://mobile.outsourcing-pharma.com/Product-Categories/Contract-Manufacturing/ImmunoCellular-tapsPharmaCell-to-manufacture-dendritic-cell-based-vaccine-for-trial. [Accessed: 16-Mar-2017]

[7] GlobeNewswire, “TiGenix completes the sale of its Dutch manufacturing facility to PharmaCell Brussels Stock Exchange:TIG," Nasdaq| GlobeNewswire, 2014. [Online]. Available: http://globenewswire.com/news-release/2014/06/02/640819/10084050/en/TiGenixcompletes-the-sale-of-its-Dutch-manufacturing-facility-to-PharmaCell.html. [Accessed: 16-Mar-2017].

[8] T. Staton and E. Palmer, “Dendreon 'monetizes' NJ plant with \$43M sale to Novartis | FiercePharma,” FiercePharma, 2012.

[Online]. Available: http://www.fiercepharma.com/m-a/dendreon-monetizes-nj-plant-43m-sale-to-novartis. [Accessed: 16-Mar-2017].

[9] New jersey business, “Novartis buys Morris Plains drug manufacturing site in \$43M deal | NJBIZ,” New Jersey business, 2012. [Online]. Available: http://www.njbiz.com/article/20121220/NJBIZ01/121229984/novartis-buys-morris-plains-drug-manufacturing-site-in43m-deal. [Accessed: 16-Mar-2017].

[10] HollandBio, “Kite Pharma Acquires T-Cell Factory for \$21M Up Front - Nieuws - HollandBIO,” HollandBIO. [Online].

Available: https://www.hollandbio.nl/nieuwsberichten/kite-pharma-acquires-t-cell-factory-for-21m-up-front. [Accessed: 16-Mar-2017].

[11] InvestHolland, “Kite Pharma Acquires Dutch Biotech Firm to Establish Amsterdam EHQ - NFIA,” Investinholland, 2015.

[Online]. Available: http://investinholland.com/kite-pharma-acquires-dutch-biotech-firm-to-establish-amsterdam-ehq/. [Accessed: 16-Mar2017].

[12] R. Dirks, "PSTI driven by High-Volume Manufacturing Capabilities, Proprietary Stem Cells and New positive Phase I clinical data for PAD,” Pluristem, 2011. [Online]. Available: http://pluristem.netron-webs.com/images/stories/publications/BioMedReports14.11.11.pdf. [Accessed: 16-Mar-2017].

[13] StreetInsider, "Pluristem (PSTI) Initiates IQ Process at cGMP Facility,” StreetInsider.com, 2012. [Online]. Available: https://www.streetinsider.com/Corporate+News/Pluristem+(PSTI)+Initiates+IQ+Process+at+cGMP+Facility/7809785.html. [Accessed: 16Mar-2017].

[14] N. Princeton, “The Seattle Times: Business \&amp; Technology: Cray posts surprise loss on defense sales decline,” The Seattle times, 2004. [Online]. Available: http://old.seattletimes.com/html/businesstechnology/2001916192_bizbriefs30.html. [Accessed: 16-Mar2017].

[15] R. Berenson, “XCYTE THERAPIES INC (Form: S-1, Received: 10/10/2003 17:31:55),” www.nasdaq.com, 2003. [Online]. Available: http://www.nasdaq.com/markets/ipos/filing.ashx?filingid=2378531. [Accessed: 16-Mar-2017].

[16] K. Kavanaugh, “Aastrom expands operations, expects to add more than a dozen positions,” metromode, 2007. [Online].

Available: http://www.secondwavemedia.com/metromode/innovationnews/aastrom2707.aspx. [Accessed: 16-Mar-2017].

[17] GlobeNewswire, “Aastrom and ATEK Medical Form Strategic Manufacturing and Development Partnership Nasdaq:ASTM,” Nasdaq|GlobeNewswire, 2010. [Online]. Available: https://globenewswire.com/news-release/2010/10/26/432419/204763/en/Aastrom-andATEK-Medical-Form-Strategic-Manufacturing-and-Development-Partnership.html. [Accessed: 16-Mar-2017].

[18] Areadevelopment, "Belgium-Based Cardio3 BioSciences To Open Facility In Rochester, Minnesota - Area Development," www.areadevelopment.com, 2015. [Online]. Available: http://www.areadevelopment.com/newsItems/3-3-2015/cardio3-biosciencesrochester-minnesota423355.shtml. [Accessed: 16-Mar-2017].

[19] Penn Medicine News, "Novartis-Penn Center for Advanced Cellular Therapeutics Unveiled at Penn Medicine - PR News,” Penn Medicine News, 2016. [Online]. Available: https://www.pennmedicine.org/news/news-releases/2016/february/novartispenn-center-foradvanc. [Accessed: 16-Mar-2017]

[20] Cell Medica, “Transforming the Treatment of Cancer and Infections," in UCL cell therapy MBI, 2014.

[21] Personal communication with Eric Matthieu, COO MaSTherCell. 2016.

[22] MaSTherCell, “MaSTherCell - Take a Tour,” MaSTherCell. [Online]. Available: http://www.masthercell.com/Take-a-Tour. [Accessed: 16-Mar-2017].

[23] J. Carroll, “Dendreon blueprints \$70M Provenge facility in Atlanta | FierceBiotech,” FierceBiotech, 2009. [Online]. Available: http://www.fiercebiotech.com/biotech/dendreon-blueprints-70m-provenge-facility-atlanta. [Accessed: 17-Mar-2017].

[24] Bzjournals, "Dendreon may put plant in Atlanta - Atlanta Business Chronicle,” bzjournals.com, 2009. [Online]. Available: http://www.bizjournals.com/atlanta/stories/2009/07/13/daily99.html. [Accessed: 17-Mar-2017]. 
Table 2 Reported values for cleanroom costs (\$ per $\mathrm{m}^{2}$ )

$\begin{array}{lccclc}\text { Barak \& } & \text { Chester } & \text { Gering \& } & \text { Gering \& } & \text { Petrides et al } & \text { Phmorma } \\ \text { Bader } & \text { Campesi } & \text { Campesi } & \text { (2008)[2] } & \text { (2015)[4] } & \text { Concepts } \\ \text { (2008)[1] } & & & (2013)[3] & & \text { (2018)[5] }\end{array}$

Mechanical rooms

(utilities)

\begin{tabular}{|c|c|c|c|c|c|c|}
\hline Office space & 2,260 & & & & $732-882$ & 1,334 \\
\hline Laboratory & 3,874 & & & & $1,463-2,937$ & 4,734 \\
\hline Class 100,000 & 4,519 & & & & 2,937-3,669 & 4,734 \\
\hline Class 10,000 & 5,003 & 5,380 & $5,703-7,123$ & $5,810-6,822$ & $3,669-5,089$ & 5,692 \\
\hline Class 1,000 & 5,649 & 7,532 & 7,446-8,554 & 7,575-8,716 & 6,531-8,802 & 7,758 \\
\hline Class 100 & & 9,684 & $\begin{array}{c}9,437- \\
10,760\end{array}$ & $\begin{array}{l}9,619- \\
11,836\end{array}$ & $\begin{array}{l}8,802- \\
11,739\end{array}$ & \\
\hline
\end{tabular}

[1] B. Barak and B. Bader, "Lifecycle Cost Analysis for Single-Use Systems," Biopharm International, Nov-2008.

[2] J. Chester, "Isolators v. RABS: Isolators v. RABS: Facility Design Considerations for Facility Design Considerations for a Fill a Fill - -Finish Suite Finish Suite,” in APV Basle conference, 2008.

[3] J. Gering and C. Campesi, "Facility Construction Outlook: Costs Stable \&amp; Trending Up,” Controlled enviroments, 2013. [Online]. Available: http://www.cemag.us/article/2013/12/facilityconstruction-outlook-costs-stable-trending. [Accessed: 03-Mar-2017].

[4] D. Petrides, R. Harrison, P. Todd, S. Rudge, and D. Petrides, "Bioprocess Design and Economics Bioseparations Science and Engineering (2 nd Edition),” 2015.

[5] eXmoor Pharma Concepts, "Personal communication with Andrew Besso - Bioprocess consultant.” 2017. 
Table 3 Ratio between the footprint of the different sections within a facility and the footprint of the product manufacture area

\begin{tabular}{lll}
\hline Facility section & Facility section & Area/Product manufacture area \\
\hline Product manufacture & Product manufacture & 1.000 \\
Clean change 1 & Clean circulation space & 0.105 \\
Clean change 2 & Clean circulation space & 0.147 \\
Clean corridors & Clean circulation space & 0.322 \\
Clean Janitor & Clean circulation space & 0.042 \\
QC labs & Product testing area & 0.650 \\
Microbiology lab & Product testing area & 0.301 \\
Labs corridor & Product testing area & 0.273 \\
PCR room & Product testing area & 0.294 \\
Janitor & Product testing area & 0.042 \\
Waste corridor & Waste circulation space & 0.804 \\
Waste change & Waste circulation space & 0.042 \\
Waste treatment & Waste circulation space & 0.168 \\
Logistics & General space & 1.077 \\
Offices & General space & 3.147 \\
Meeting rooms & General space & 0.105 \\
Stairs & General space & 0.231 \\
Cold rooms & General space & 0.168 \\
Janitor & General space & 0.042 \\
General corridor & General space & 0.399 \\
Lorry/Van loading docks & General space & 0.224 \\
Reception & General space & 0.538 \\
WC & General space & 0.392 \\
Plant level & Plant space & 4.755 \\
\hline The & atios &
\end{tabular}

The ratios between the cleanroom area and the footprint of all other sections within a facility were derived from materials provided by and personal communication with Andrew Besso and Paul Dempsey (eXmoor Pharma Concepts, Bristol, UK) 
Table 4 Key case study assumptions

\begin{tabular}{|c|c|c|}
\hline Parameter & Value & Unit \\
\hline Dose size & $100 \mathrm{M}$ & cells/dose \\
\hline No batches per year (allogeneic) & 20 & batches/year \\
\hline Equipment area/ product manufacture area ${ }^{a}$ & 0.163 & - \\
\hline Material airlock footprint ${ }^{\mathrm{b}}$ & 6 & $\mathrm{~m}^{2}$ \\
\hline Personnel airlock footprint ${ }^{\mathrm{b}}$ & 6 & $\mathrm{~m}^{2}$ \\
\hline No QC labs/ facility & 1 & - \\
\hline Process support equipment costs ${ }^{\mathrm{b}}$ & 2,389 & $\$ / \mathrm{m}^{2}$ of cleanroom \\
\hline Logistics equipment costs ${ }^{\mathrm{b}}$ & 548 & $\$ / \mathrm{m}^{2}$ of cleanroom \\
\hline EMS central unit ${ }^{\mathrm{b}}$ & 108,800 & \$/unit \\
\hline Probe costs ${ }^{\mathrm{b}}$ & 1,920 & \$/sampling point \\
\hline Equipment installation costs ${ }^{\mathrm{C}}$ & 1,920 & \$/unit \\
\hline Building shell costs ${ }^{\mathrm{b}}$ & 548 & $\$ / m^{2}$ \\
\hline Fit-out costs (Grade B) ${ }^{\mathrm{b}}$ & 8,320 & $\$ / \mathrm{m}^{2}$ \\
\hline Fit-out costs (Grade C) ${ }^{b}$ & 6,106 & $\$ / m^{2}$ \\
\hline Fit-out costs (Grade D) ${ }^{\mathrm{b}}$ & 5,082 & $\$ / \mathrm{m}^{2}$ \\
\hline Fit-out costs $(\mathrm{CNC})^{\mathrm{b}}$ & 1,741 & $\$ / m^{2}$ \\
\hline Fit-out costs (unclassified) ${ }^{\mathrm{b}}$ & 64 & $\$ / m^{2}$ \\
\hline Contractor fees ${ }^{\mathrm{b}}$ & $12 \%$ & of Fit-out costs \\
\hline Land costs ${ }^{\mathrm{d}}$ & $6 \%$ & of Shell costs \\
\hline Yard improvement costs ${ }^{\mathrm{d}}$ & $10 \%$ & of Shell costs \\
\hline Engineering, management and consultant fees ${ }^{\mathrm{b}}$ & $20 \%$ & of Direct costs \\
\hline Contingency costs ${ }^{\mathrm{b}}$ & $20 \%$ & $\begin{array}{l}\text { of (Direct costs + Engineering, } \\
\text { management and consultant fees) }\end{array}$ \\
\hline
\end{tabular}

EMS = environment monitoring systems; CNC = controlled and non-classified

${ }^{a}$ Derived from floorplans of different cell therapy facilities

${ }^{b}$ Derived from materials provided by and personal communication with Andrew Besso and Paul Dempsey (eXmoor Pharma Concepts, Bristol, UK)

'Derived from personal communication with Eric Matthieu (MaSTherCell, Gosseles, Belgium)

$\mathrm{d}[38]$ 
Table 5 Key characteristics of the manufacturing platforms included in this case study

\begin{tabular}{|c|c|c|c|c|c|c|c|}
\hline $\begin{array}{l}\text { Donor } \\
\text { type }\end{array}$ & Manufacturing platform & Abbreviation & $\begin{array}{l}\text { Key technologies } \\
\text { required }^{\mathrm{a}}\end{array}$ & $\begin{array}{l}\text { Max capacity/unit } \\
\text { (no doses in } \\
\text { parallel) }\end{array}$ & $\begin{array}{l}\text { Max no of } \\
\text { batches per } \\
\text { cleanroom }\end{array}$ & Costs/unit (\$) & $\begin{array}{l}\text { Footprint/unit } \\
\left(\mathbf{m}^{2}\right)^{\mathrm{c}}\end{array}$ \\
\hline \multirow[t]{4}{*}{ Allogeneic } & Multilayer flasks & MLF & $\begin{array}{l}\text { BSC; MLINC; } \\
\text { INC40; AMLFM; } \\
\text { FBC }\end{array}$ & $\begin{array}{l}500 ; 31 ; 164 ; 28 ; \\
10,000\end{array}$ & NA & $\begin{array}{l}\text { 12,800; 13,440; } \\
\text { 198,016; } \\
\text { 482,560; 261,162 }\end{array}$ & $\begin{array}{l}1 ; 0.46 ; 2.9 ; \\
2.3 ; 0.77\end{array}$ \\
\hline & Multi-plate bioreactor & MPB & $\begin{array}{l}\text { BSC; MLINC; } \\
\text { MPBC; FBC }\end{array}$ & $\begin{array}{l}500 ; 9-64 ; 1-32 \\
; 10,000\end{array}$ & NA & $\begin{array}{l}12,800 ; 56,000 \\
261,162\end{array}$ & $1 ; 0.46 ; 0.2 ; 0.77$ \\
\hline & Hollow fibre bioreactor & HFB & BSC; HFB; FBC & $500 ; 5 ; 10,000$ & NA & $\begin{array}{l}12,800 ; 150,000 \\
261,162\end{array}$ & $1 ; 0.3 ; 0.77$ \\
\hline & Stirred tank bioreactor & STR & BSC; STR; FBC & $500 ; 1-2,898 ; 10,000$ & NA & $\begin{array}{l}\text { 12,800; 35,584- } \\
291,886 ; \\
261,162\end{array}$ & $1 ; 0.87-4.2 ; 0.77$ \\
\hline \multirow[t]{4}{*}{ Autologou } & $\begin{array}{l}\text { sMultilayer flasks with open } \\
\text { steps }\end{array}$ & MLF (open) & $\begin{array}{l}\text { BSC; MLINC; } \\
\text { SMF }\end{array}$ & $2 ; 5 ; 2$ & 1 & $\begin{array}{l}12,800 ; 13,440 \\
79,429\end{array}$ & $1 ; 0.46 ; 0.35$ \\
\hline & Static suspension bags & SSB & MLINC; SMF & $5 ; 2$ & 5 & 13,$440 ; 79,429$ & $0.46 ; 0.35$ \\
\hline & Integrated USP/DSP platform & INT & INT & 1; & 20 & 235,500 & 0.38 \\
\hline & Rocking motion bioreactor & RMB & $\begin{array}{l}\text { MLINC; RMB; } \\
\text { SMF }\end{array}$ & $5 ; 1 ; 2$ & 10 & $\begin{array}{l}13,440 ; 47,500 \\
79,429\end{array}$ & $0.46 ; 0.22 ; 0.35$ \\
\hline
\end{tabular}

${ }^{a}$ main process equipment required where: BSC = biosafety cabinet; MLINC = multilayer flask incubator; INC40 = 40-layer flask incubator; AMLFM = automated multilayer flask manipulator; FBC= fluidised bed centrifuge; $\mathrm{MPBC}=$ multi-plate bioreactor controller; $\mathrm{HFB}$ = hollow fibre bioreactor; STR = stirred tank bioreactor ( $\mathrm{w}$ microcarriers); SMF = spinning membrane filtration unit; INT = integrated USP/DSP platform; RMB = rocking motion bioreactor. For allogenic processes, this capacity is calculated under the assumption that a harvest density of $45,000 \mathrm{cells} / \mathrm{cm}^{2}$ was achieved and that microcarrier-based processes offer $5,540 \mathrm{~cm}^{2} / \mathrm{L}$.

${ }^{\mathrm{b}}$ number of doses of $100 \mathrm{M}$ cells which can be produced using each technology. For MPB multiple bioreactor sizes were considered (with 10 plates. 50 plates, 100 plates and 200 plates), these bioreactors use the same controller, hence a range in capacity is seen. In STR a range in the capacity of the bioreactor is also seen as multiple bioreactor sizes were also considered $(1 \mathrm{~L}, 5 \mathrm{~L}, 10 \mathrm{~L}, 20 \mathrm{~L}, 50 \mathrm{~L}, 100 \mathrm{~L}, 500 \mathrm{~L}, 1,000 \mathrm{~L}$ and 2,000L).

${ }^{\mathrm{c}}$ For equipment with large volumes ( STR 100L, STR 500L, STR 1,000L and STR 2,000L), footprint includes auxiliary equipment (e.g. holding tanks for media and harvest) 
Table 6 Cost factor breakdown for different hypothetical cell therapy facilities producing 5,000 doses of 100M cells per year

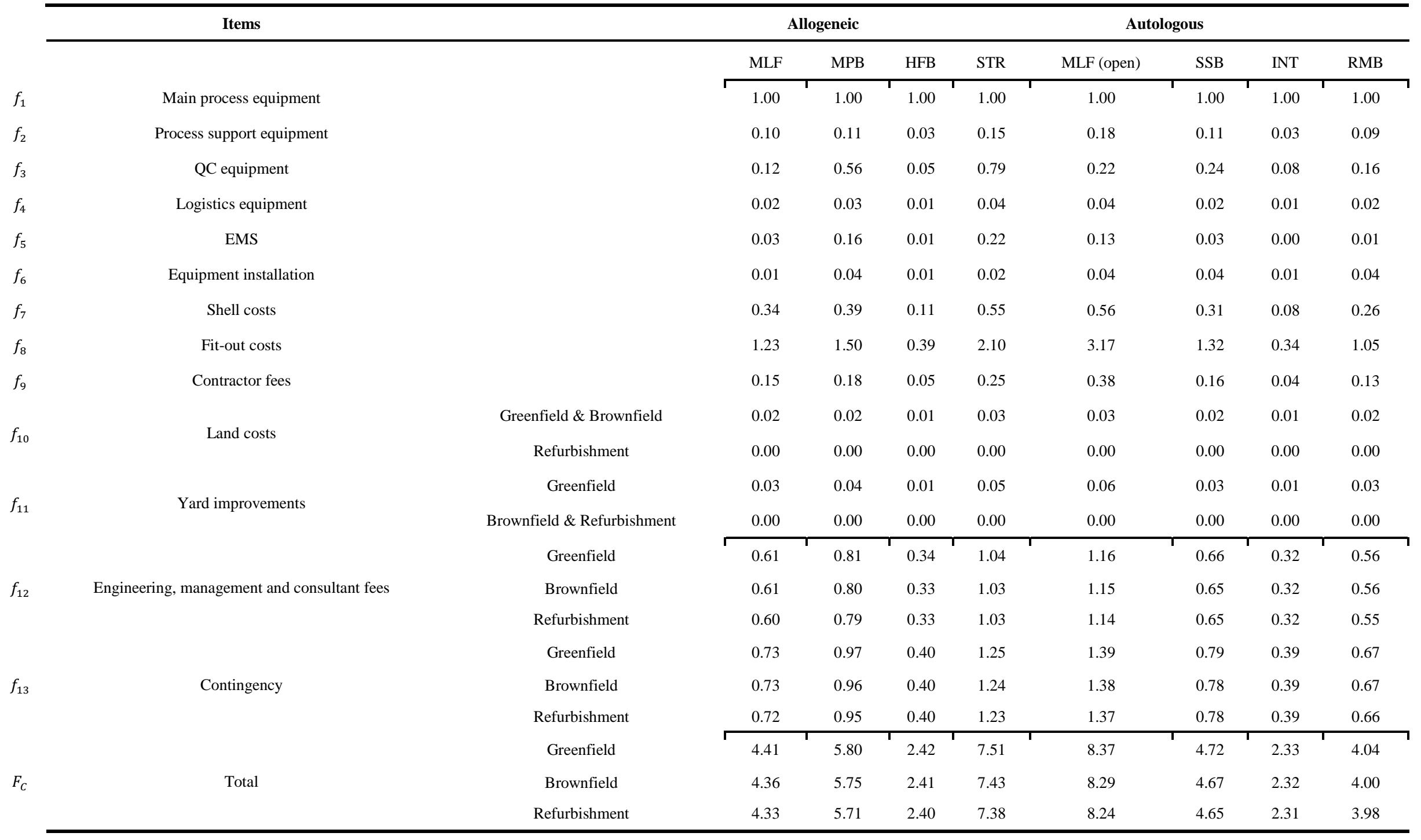


Supplementary Table 1 List of equipment required per QC lab and their unit costs

\begin{tabular}{lc}
\hline Equipment & Costs (\$/unit) \\
\hline Balance (200g) & 2,408 \\
Cell Counter & 2,816 \\
CO2 incubator & 13,440 \\
ELISA/Spectrophotometer & 51,200 \\
Endotoxin Test & 12,800 \\
FACS & 128,000 \\
Filter Integrity Tester & 12,800 \\
FTIR & 8,658 \\
Gel Analysis Instrument & 1,920 \\
HPLC & 64,000 \\
Isolator, Grade A with VHP & 153,600 \\
Microscope & 12,160 \\
MSCII & 12,800 \\
Osmometer & 16,698 \\
PCR & 57,600 \\
PCR Hood - mini LAF for PCR amplification & 12,800 \\
pH Meter & 1,039 \\
Plate Reader & 6,221 \\
Power Packs & 1,007 \\
Peristaltic Pump & 1,386 \\
Sterility Test & 153,600 \\
Turbidity Meter & 963 \\
\hline
\end{tabular}

ELISA = enzyme-linked immunosorbent assay; FACS = fluorescence-activated cell sorting; FTIR = Fourier-transform infrared spectroscopy; HPLC = high performance liquid chromatography; VHP = vapour hydrogen peroxide; MSCII = class II microbial safety cabinet; PCR = polymerase chain reaction

The list of typical QC equipment in a cell therapy facility was derived through discussions with lab scientists and industrial experts. The individual equipment costs were obtained from vendor websites. 
a)

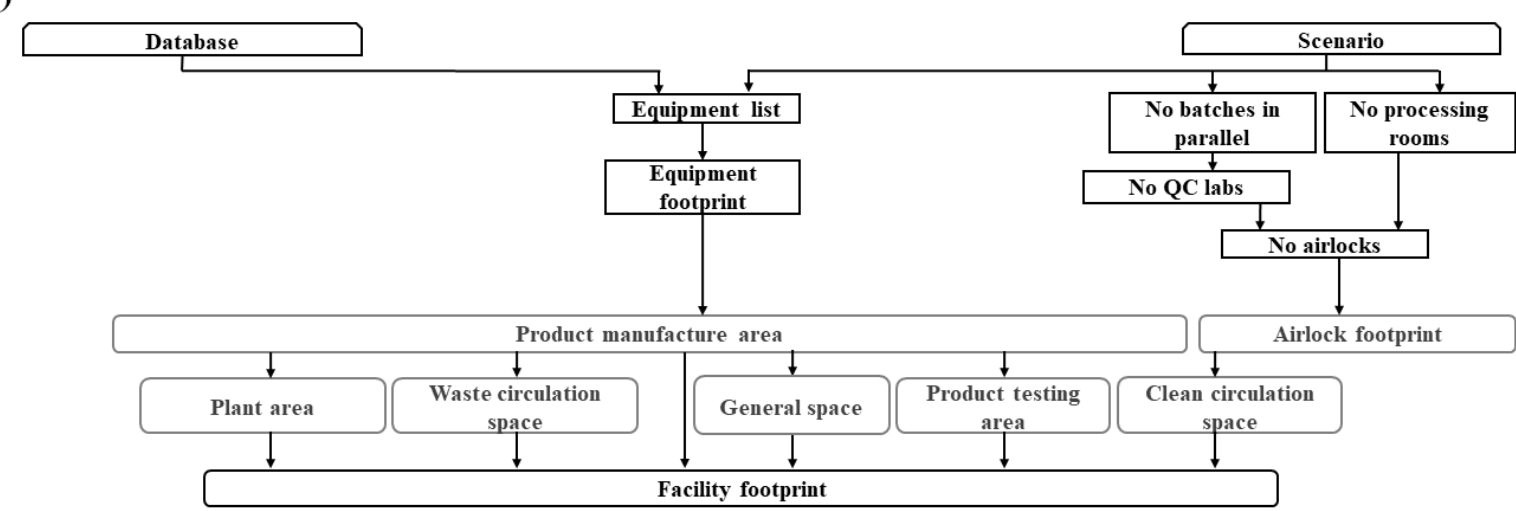

b)

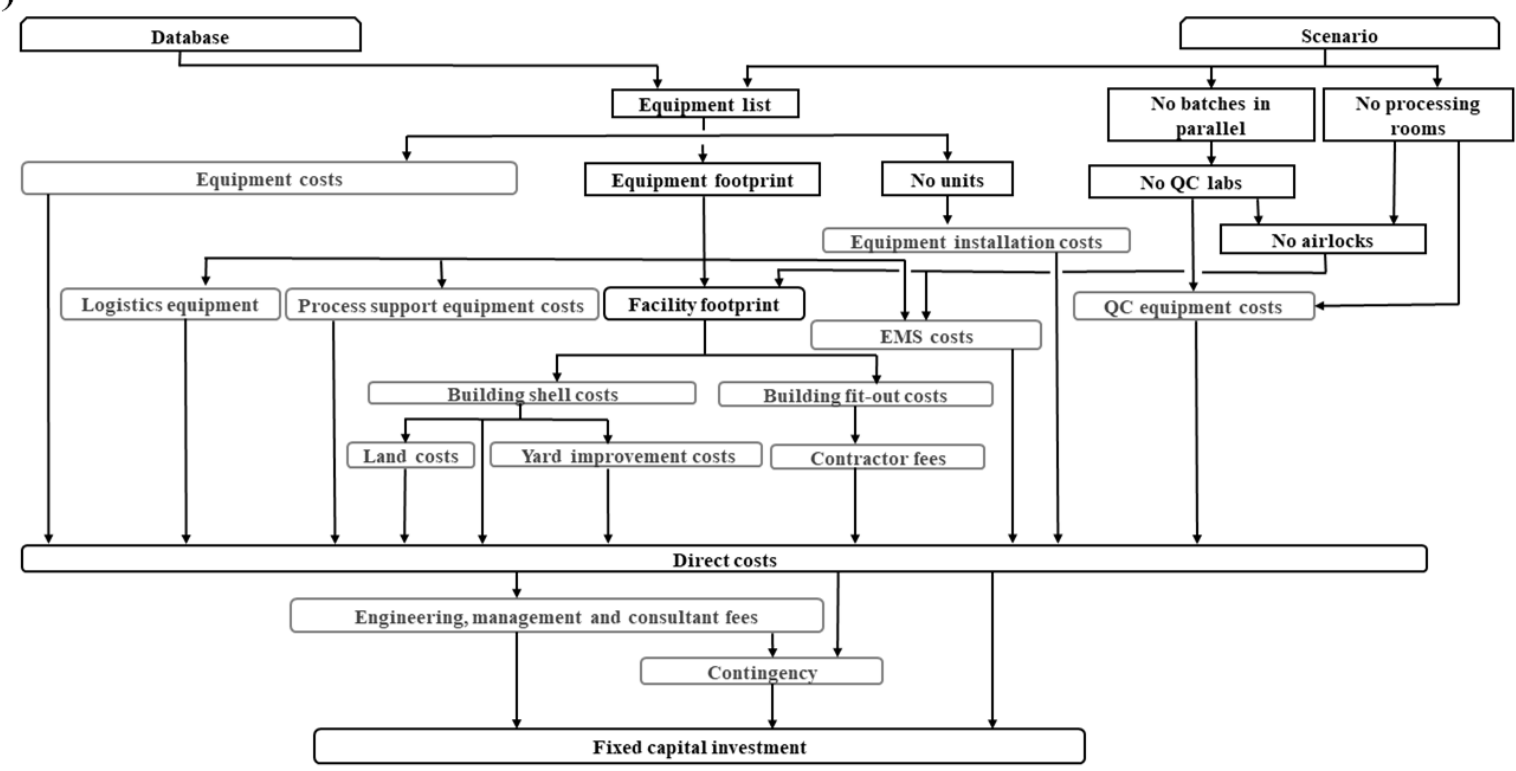

Figure 1 Schematic representation of the detailed factorial methodology used for estimating a) facility footprint b) FCI evaluation. 
a)

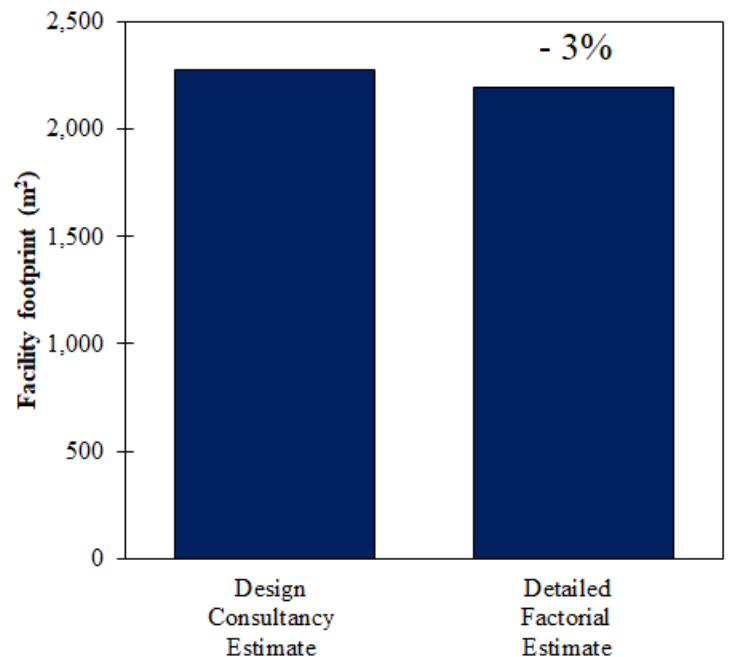

b)

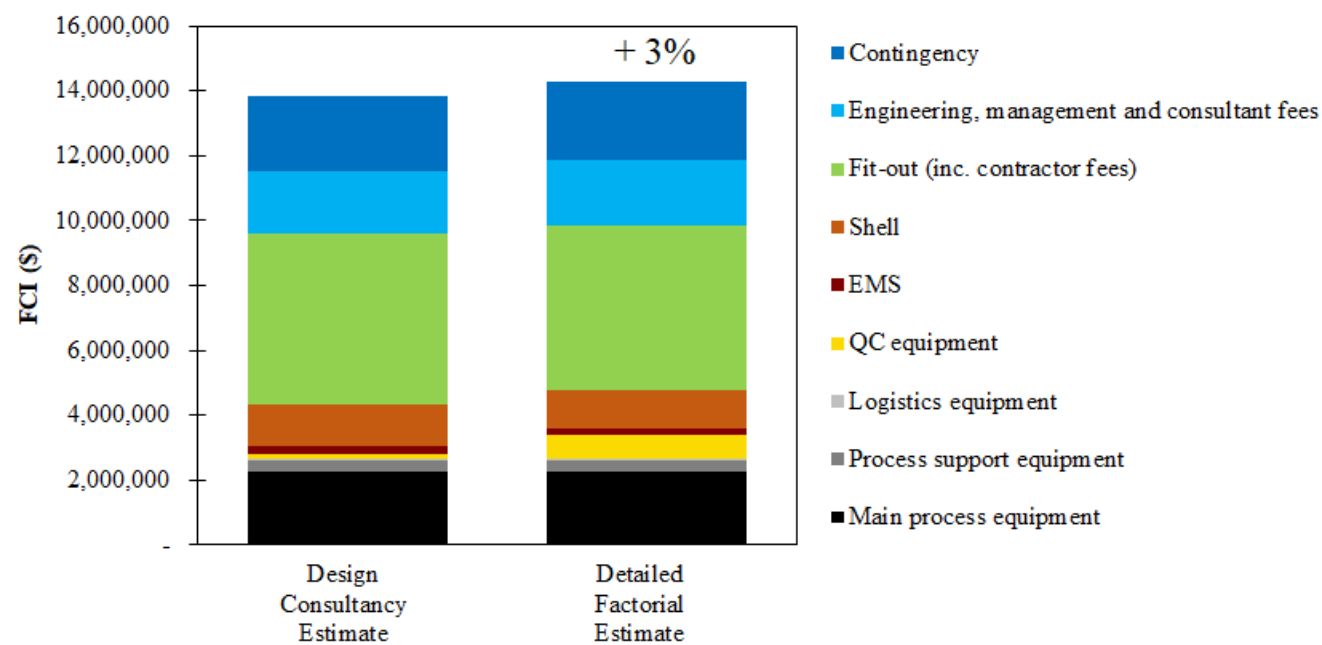

Figure 2 Comparison between results attained using the novel detailed factorial method for FCI and facility footprint evaluation and those provided by a design consultancy, eXmoor Pharma Concepts, for a) facility footprint and b) FCI. The scenario selected shown here corresponds to a greenfield project in a medium economically developed country. 
a)
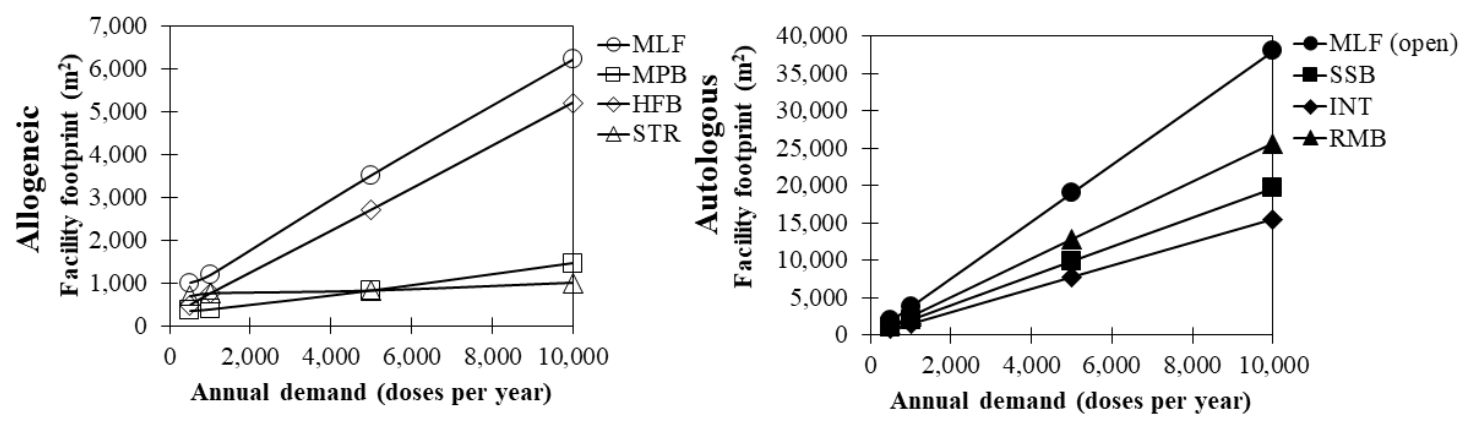

b)
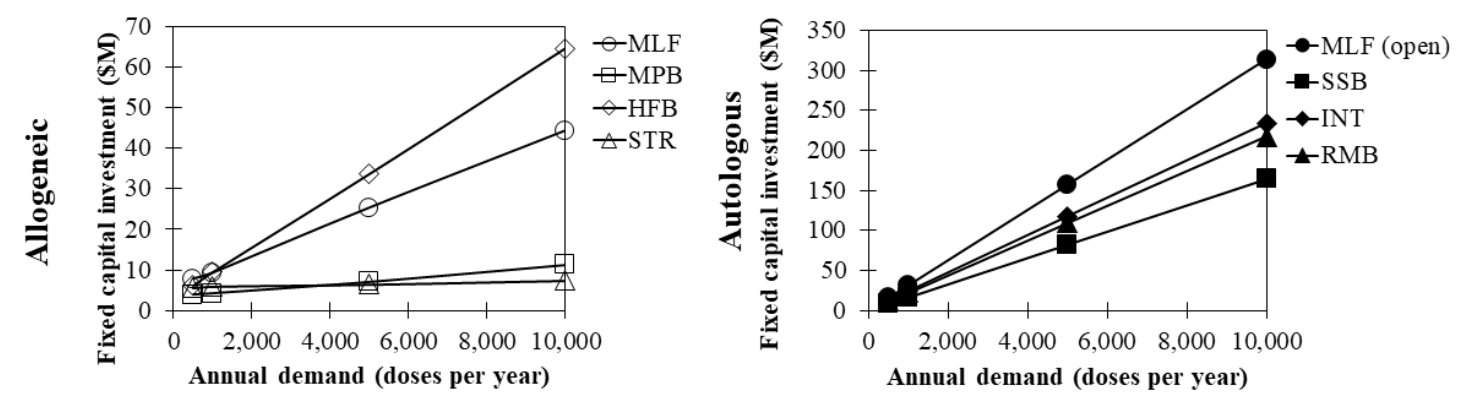

Figure 3 a) Facility footprint and b) FCI with increasing annual demand for different manufacturing platforms. The unit operations included in the allogenic platforms were inoculation, cell culture and wash and volume reduction while the unit operations included in the autologous platforms were elutriation, cell wash, cell selection, cell activation, viral transduction, cell culture and wash and volume reduction. For allogenic processes a harvest density of 45,000 cells $/ \mathrm{m}^{2}$ for all platforms and surface area/L for microcarrier-based platforms of $5,540 \mathrm{~cm}^{2} / \mathrm{L}$ were assumed. For autologous processes a maximum cell density for cell culture was $7 \times 10^{6}$ cells/ml was assumed. The scenario selected shown here corresponds to a greenfield project in a medium economically developed country. The abbreviations indicate the name of the different manufacturing platforms: MLF = multilayer flask; MPB = multi-plate bioreactor; HFB = hollow fibre bioreactor; STR = stirred tank bioreactor; MLF (open) = multilayer flask with open steps; SSB = static suspension bag; INT = integrated USP/DSP platform; RMB = rocking motion bioreactor. 
a)

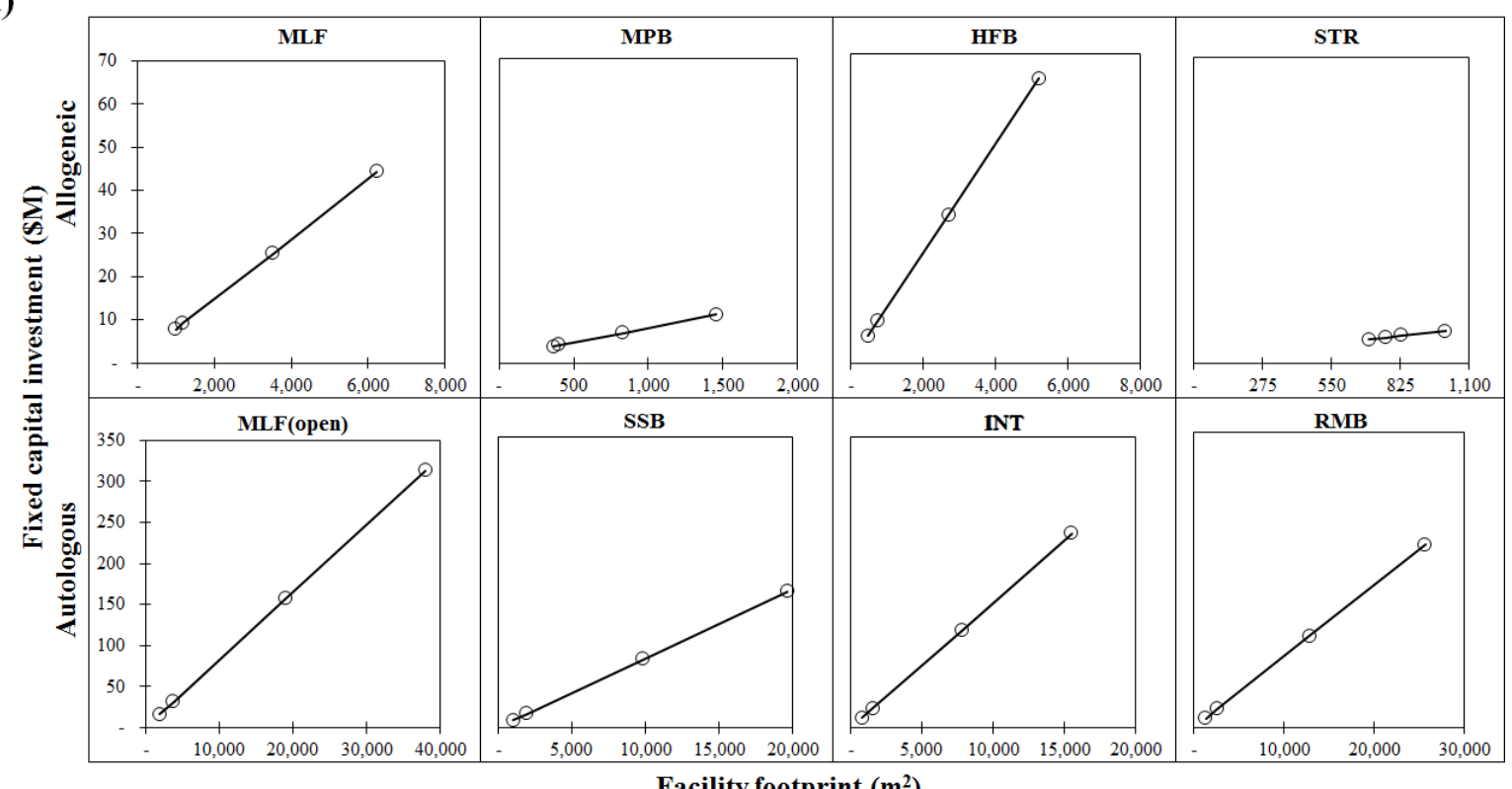

b)

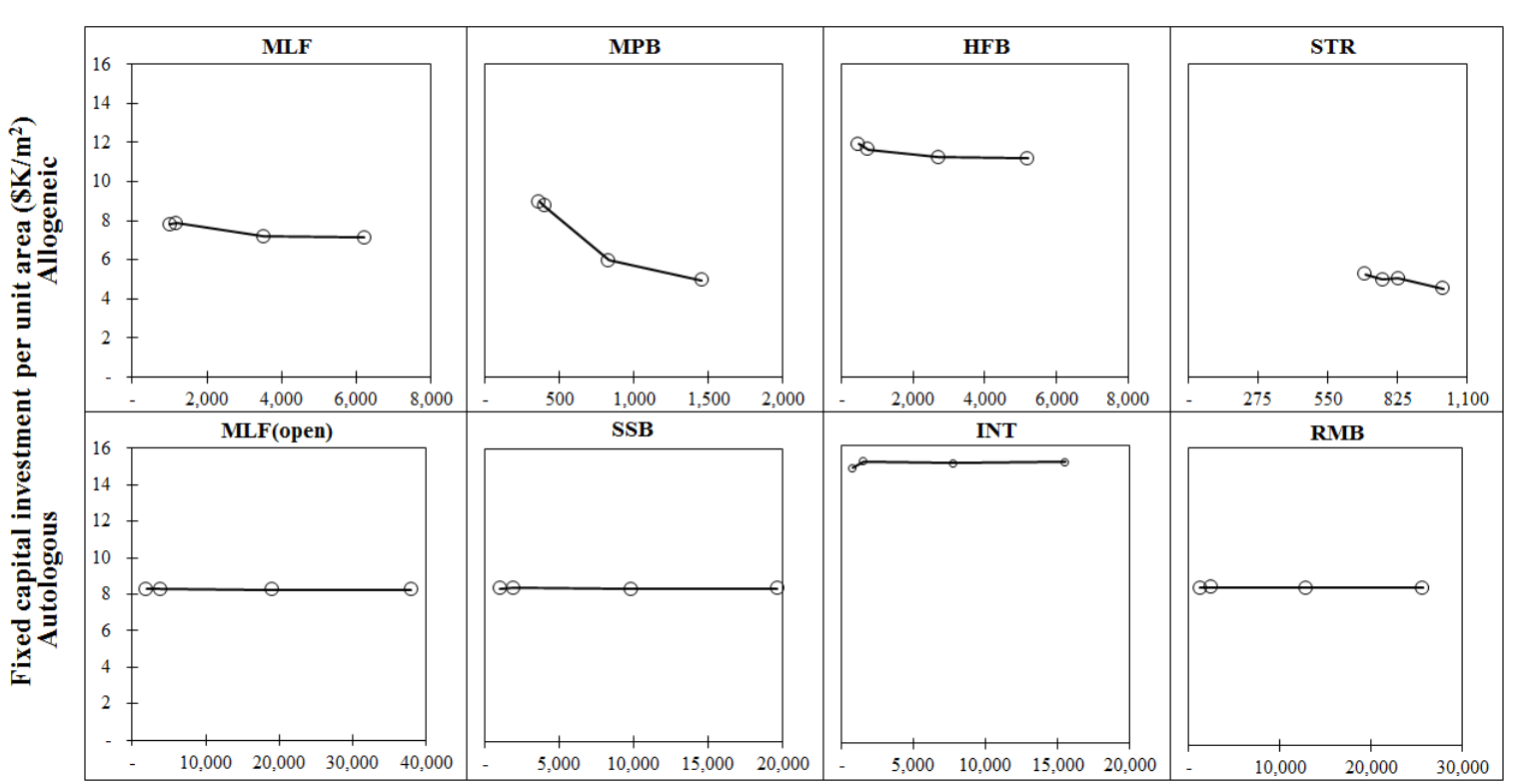

Facility footprint $\left(\mathbf{m}^{2}\right)$

Figure 4 Relationship between a) FCI and facility footprint and b) FCI per $\mathrm{m}^{2}$ of facility and facility footprint across multiple manufacturing platforms. The unit operations included in the allogenic platforms were inoculation, cell culture and wash and volume reduction while the unit operations included in the autologous platforms were elutriation, cell wash, cell selection, cell activation, viral transduction, cell culture and wash and volume reduction. For allogenic processes a harvest density of 45,000 cells $/ \mathrm{cm}^{2}$ for all platforms and surface area/L for microcarrier-based platforms of $5,540 \mathrm{~cm}^{2} / \mathrm{L}$ were assumed. For autologous processes a maximum cell density for cell culture was $7 \times 10^{6}$ cells $/ \mathrm{ml}$ was assumed. The scenario selected shown here corresponds to a greenfield project in a medium economically developed country. The abbreviations indicate the name of the different manufacturing platforms: MLF = multilayer flask; MPB = multi-plate bioreactor; HFB = hollow fibre bioreactor; $\mathrm{STR}=$ stirred tank bioreactor; MLF (open) = multilayer flask with open steps; SSB = static suspension bag; INT = integrated USP/DSP platform; RMB = rocking motion bioreactor. 


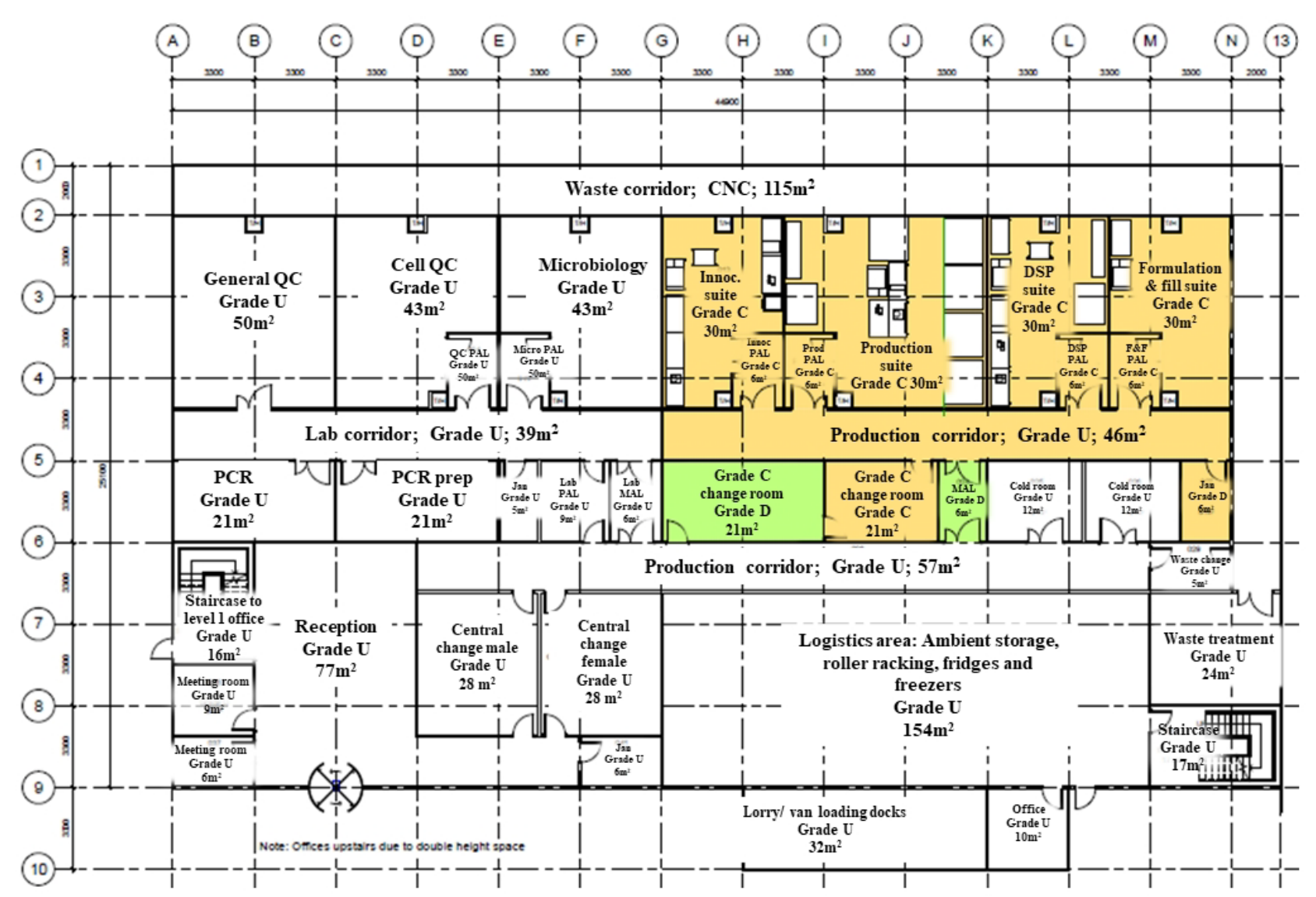

Figure 5 General facility layout used in this analysis to determine the relative footprint of the different areas within a cell therapy facility. Yellow regions = Grade C area classification; Green regions = Grade D area classification; white regions $=$ Grade $\mathrm{U}$ area classification . Diagram generated by eXmoor Pharma Concepts. 


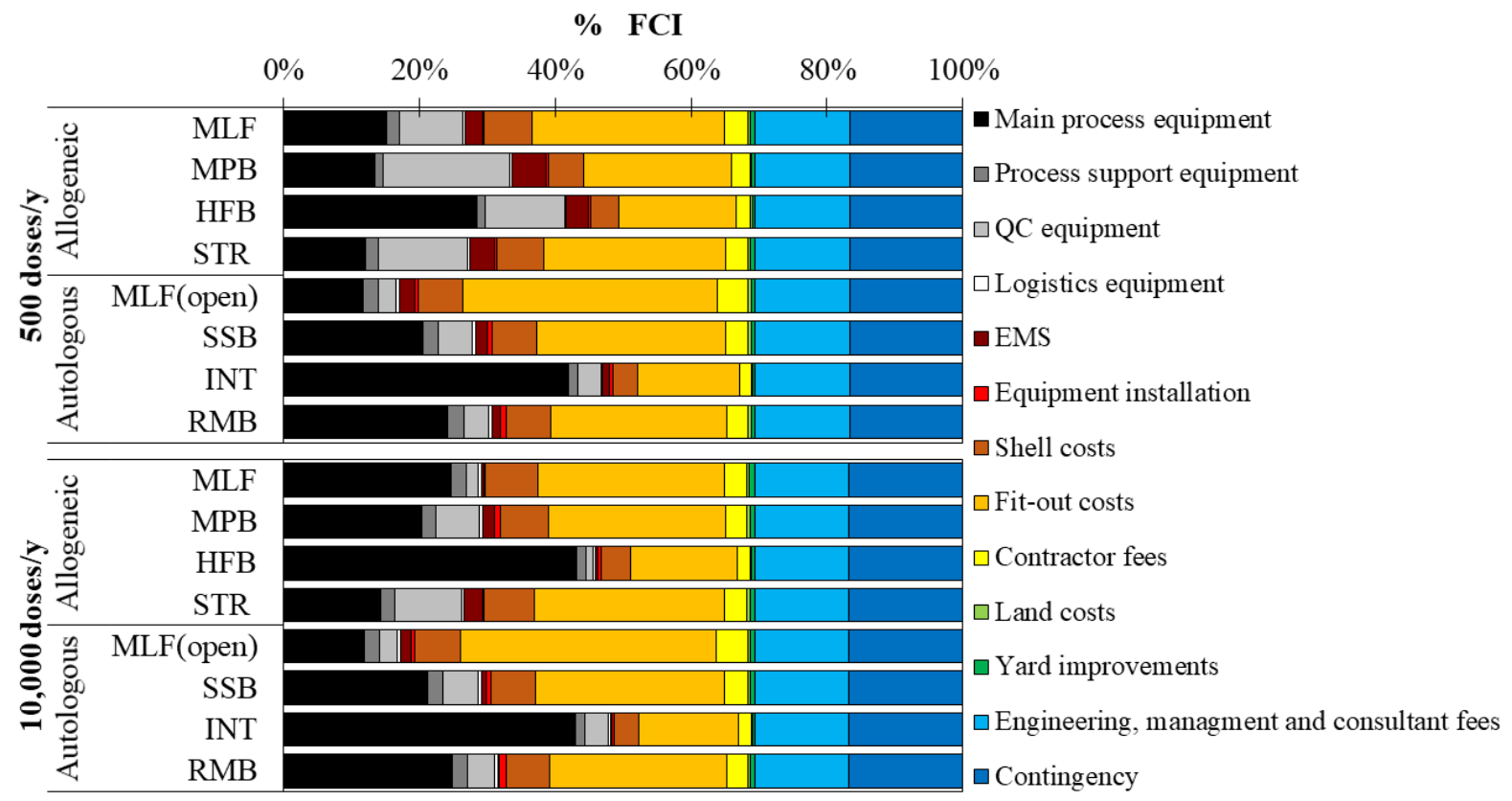

Figure 6 Contribution of the different factors towards the FCI for a dose size of $100 \mathrm{M}$ cells and annual demands of 500 and 10,000 doses per year. The scenario selected shown here corresponds to a greenfield project in a medium economically developed country. The abbreviations indicate the name of the different manufacturing platforms: MLF = multilayer flask; $\mathrm{MPB}=$ multi-plate bioreactor; $\mathrm{HFB}=$ hollow fibre bioreactor; STR $=$ stirred tank bioreactor; MLF (open) = multilayer flask with open steps; SSB = static suspension bag; INT = integrated USP/DSP platform; RMB = rocking motion bioreactor. 

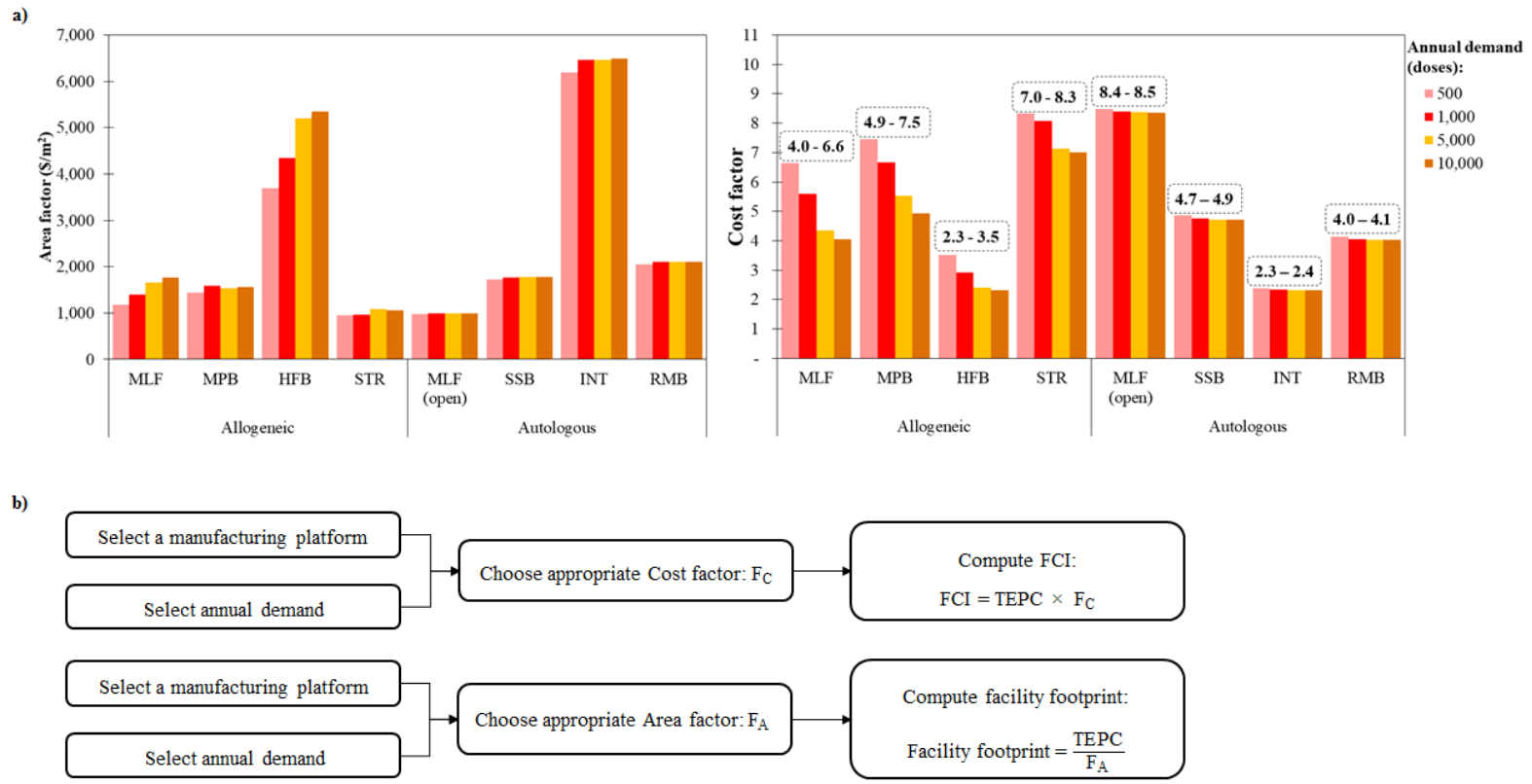

Figure 7 a) Trends in area factor and cost factor across multiple manufacturing platforms and commercialisation demand scenarios for a product with a dose size of $100 \mathrm{M}$ cells. The unit operations included in the allogenic platforms were inoculation, cell culture and wash and volume reduction while the unit operations included in the autologous platforms were elutriation, cell wash, cell selection, cell activation, viral transduction, cell culture and wash and volume reduction. For allogenic processes a harvest density of 45,000 cells $/ \mathrm{m}^{2}$ for all platforms and surface area/L for microcarrier-based platforms of $5,540 \mathrm{~cm}^{2} / \mathrm{L}$ were assumed. For autologous processes a maximum cell density for cell culture was $7 \times 10^{6}$ cells $/ \mathrm{ml}$ was assumed. The scenario selected shown here corresponds to a greenfield project in a medium economically developed country. The abbreviations indicate the name of the different manufacturing platforms: $\mathrm{MLF}=$ multilayer flask; $\mathrm{MPB}=$ multi-plate bioreactor; $\mathrm{HFB}=$ hollow fibre bioreactor; STR = stirred tank bioreactor; MLF (open) = multilayer flask with open steps; SSB = static suspension bag; INT = integrated USP/DSP platform; RMB = rocking motion bioreactor b) Method for evaluating facility footprint and FCI. 


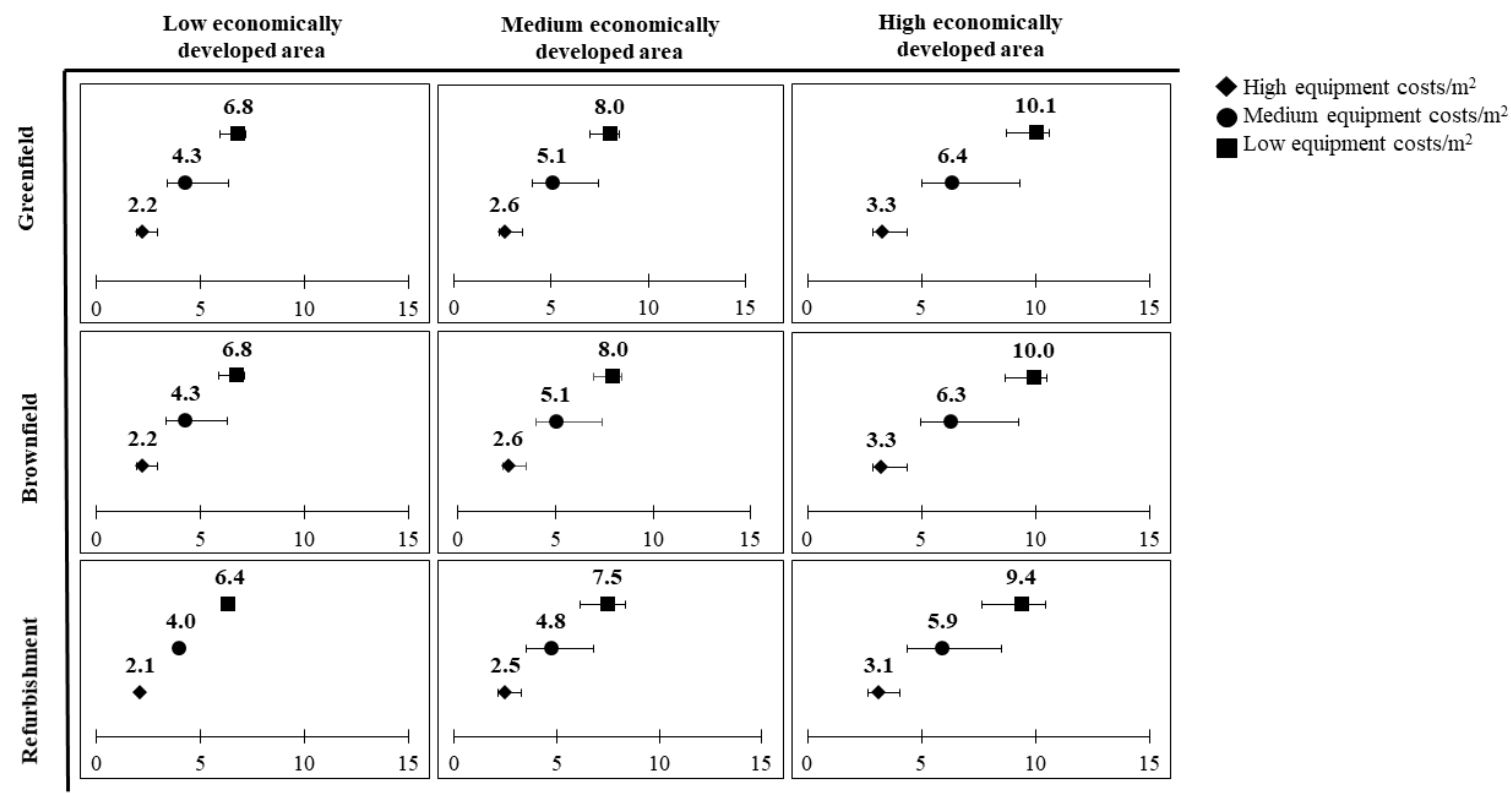

Figure 8 Change in cost factor with initial condition of the facility site, manufacturing platform and geographic location of the facility. The manufacturing platforms with high costs $/ \mathrm{m}^{2}$ are the hollow fibre bioreactor and the integrated USP/DSP. The manufacturing platforms with medium costs $/ \mathrm{m}^{2}$ are the multilayer flasks, multi-plate bioreactor, static suspension bags and rocking motion bioreactor and the manufacturing platform with low costs $/ \mathrm{m}^{2}$ are the stirred tank bioreactor and multilayer flasks with open steps. 